\title{
Quasi-Fiscal Deficits and Energy Conditionality in Selected CIS Countries
}

Tapio Saavalainen and Joy ten Berge 



\title{
IMF Working Paper
}

\author{
Middle East and Central Asia Department
}

\section{Quasi-Fiscal Deficits and Energy Conditionality in Selected CIS Countries}

\author{
Prepared by Tapio Saavalainen and Joy ten Berge ${ }^{1}$ \\ Authorized for distribution by Adam Bennett
}

February 2006

\begin{abstract}
This Working Paper should not be reported as representing the views of the IMF. The views expressed in this Working Paper are those of the author(s) and do not necessarily represent those of the IMF or IMF policy. Working Papers describe research in progress by the author(s) and are published to elicit comments and to further debate.

Quasi-fiscal deficits of public utility companies are common in all member countries of the Commonwealth of Independent States (CIS). They constitute a significant impediment to efficient resource allocation and endanger macroeconomic stability. This paper presents a simple framework for measuring and monitoring such deficits and highlights their macroeconomic relevance. It reviews the progress under IMF conditionality aimed at correcting these imbalances during 1993-2003. The paper suggests that the extensive conditionality under the IMF-supported programs has yielded only limited progress in reducing the energy sector's financial imbalances. In conclusion, different policy options are discussed in light of the lessons learned.

JEL Classification Numbers: L71, E62, P21, F33, H11

Keywords: Energy, quasi-fiscal deficit, transition, conditionality, governance

Author(s) E-Mail Address: tsaavalainen@imf.org, jtenberge@imf.org

\footnotetext{
${ }^{1}$ Mr. Saavalainen was an Advisor in the Middle East and Central Asia Department when this paper was written. Ms. ten Berge is an economist in the same department. Mr. Travis and Ms. Ebinger (both World Bank) cooperated closely with the authors during the study. Ms. Abajyan provided excellent research assistance in building the initial database. The authors are grateful to the country desks for providing information and helpful comments. All remaining errors are the authors'.
} 


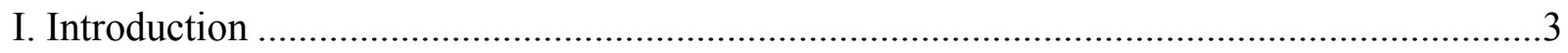

II. Measuring the Quasi-Fiscal Deficit...........................................................................

III. Macroeconomic Relevance of Quasi-Fiscal Deficits............................................... 10

IV. Energy Sector Conditionality .............................................................................. 11

A. IMF Conditionality on Electricity and Gas ............................................... 12

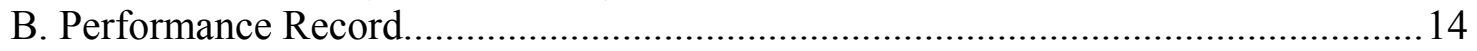

V. Outcomes and Lessons Learned........................................................................... 19

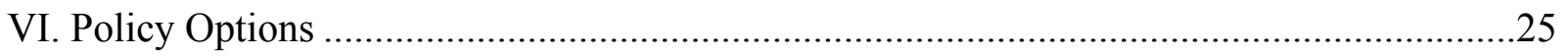

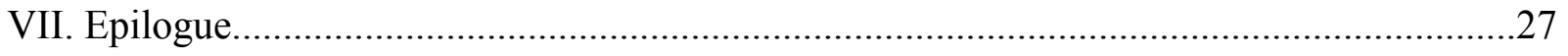

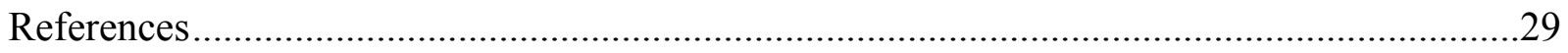

Appendix Tables

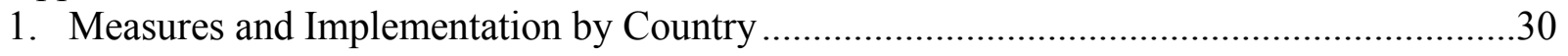

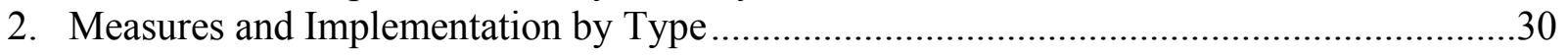

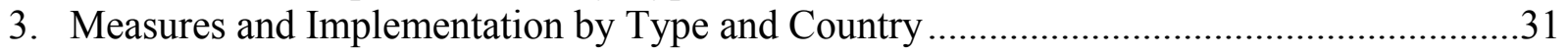

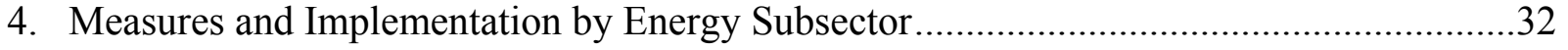

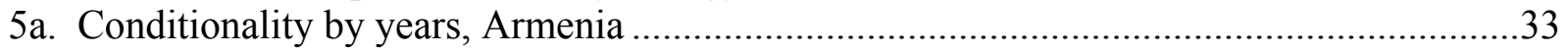

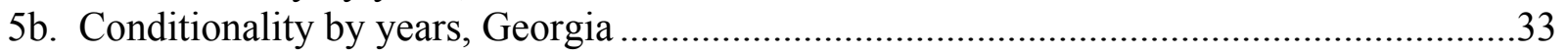

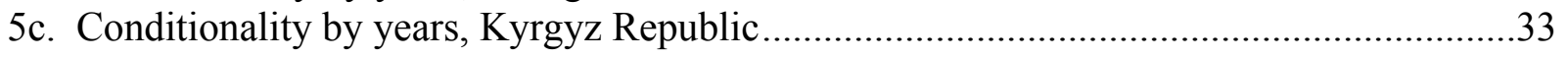

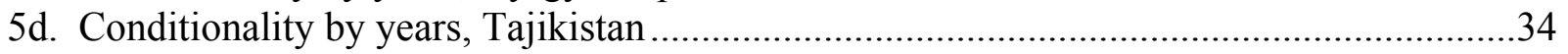

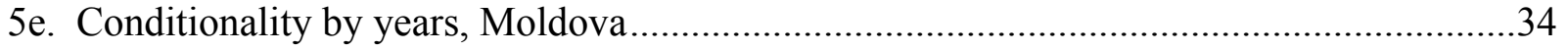

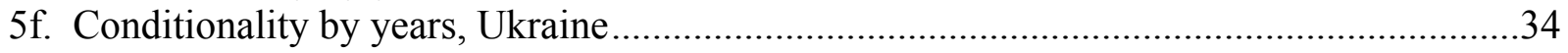

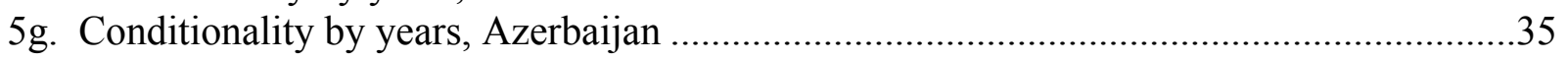

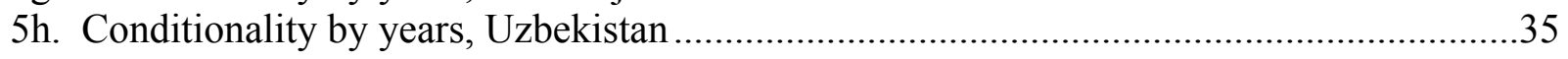




\section{INTRODUCTION}

Energy policies in the member countries of the Commonwealth of Independent States (CIS) continued to have a strong supply-side bias after the collapse of the Soviet Union. The governments' main concern was to provide energy to the population and enterprises with little attention to costs, and to the need to adjust to the emerging market economy environment. Donor-supported energy reforms aimed at reducing this supply-side bias. Reforms advocated by international financial institutions (IFIs) focused on rehabilitating the capital stock and unbundling the old, vertically integrated energy monopolies. The goal was to generate efficiency gains through privatization and sector restructuring. The demand side was addressed through tariff reforms assuming that energy demand would adjust to new prices and thus improve the efficiency of energy use. However, the intended balance of reforms between supply and demand factors suffered from severe weaknesses in implementation. The authorities continued to place emphasis on the production and distribution, while tariff and payment reforms progressed slowly. As a result, most CIS countries continued to run extensive indirect subsidization schemes for domestic energy users.

This paper quantifies such quasi-fiscal deficits (QFDs) for the electricity and gas sectors in eight CIS countries. ${ }^{2}$ The focus is on these CIS countries' as they were hardest hit and slowest to adjust to the systemic shock associated with the disintegration of the Soviet energy network. The paper reviews the related Fund conditionality under the countries' stabilization and reform programs aimed at eliminating QFDs in the energy sector to improve conditions for economic growth. The paper is organized as follows. Section II provides a framework and computations of QFDs in the sample countries. Section III highlights the macroeconomic relevance of QFDs. This is followed by a quantification of Fund conditionality on the electricity and gas sectors, and the reform record during 1993-2003 (Section IV). The discussion on the lessons learned is presented in Section V, and Section VI outlines key reform options.

\section{Measuring The Quasi-Fiscal Deficit}

This paper defines the revenue-expenditure gap of a public utility company as a quasi-fiscal deficit on two accounts. First, the utility companies are typically state-owned natural monopolies and the government — as the regulator — sets their tariffs just like it imposes taxes as a price for public goods. Second, underpricing, non-collection of bills, and commercial losses (including tolerating theft) constitute a government-sponsored collective subsidy scheme for the public. Although utility companies are largely independent in their

\footnotetext{
${ }^{2}$ Based on 2003 GNI per capita income (in U.S. dollars), the World Bank classified Ukraine, Armenia, Azerbaijan, and Georgia as low middle-income countries, and the Kyrgyz Republic, Moldova, Tajikistan and Uzbekistan as low-income countries. The study does not cover developments in the four other CIS countries: the Russian Federation, Kazakhstan, Belarus, and Turkmenistan, although the lessons learned may be applicable to those (and other transition economies) as well.
} 
operational decision making, they are quasi-fiscal agencies because of the state ownership and regulatory powers of the government which has the ultimate responsibility for service delivery as well as for financial liabilities. In transition countries, public utilities are not generally included in the general government accounts and the true cost of underfinanced utilities is not transparent to the public. The recorded budgetary support to the energy sector does not measure the total financial imbalance of the sector because a large part of the actual support to the public is implicit, including in the form of underpricing the services delivery. Defining the revenue-expenditure gap of the energy sector as a quasi-fiscal deficit is a more accurate presentation of the total subsidy involved. Thus:

\section{The quasi-fiscal deficit of state-owned public utilities is the value of implicit subsidy computed as the difference between the actual revenue charged and collected at regulated prices and the revenue required to fully cover the operating costs of production and capital depreciation.}

The measurement of the energy sector quasi-fiscal deficit is a complex task because of the implicit nature of quasi-fiscal activities. To the extent they exist, country practices to estimate the QFD vary making accurate comparisons difficult. The simplest method to achieve comparability is to apply the "end-product approach" in estimating the quasi-fiscal deficit. ${ }^{3}$ In this approach, the actual cost of energy to domestic end-users (households, industry, agriculture, and others) is compared with the cost of production at cost-recovery prices. This approach captures the implicit subsidy arising from mispricing, nonpayment of bills, and excess losses. ${ }^{4}$ The quasi-fiscal deficit equals the cost of domestic use of production $(\mathrm{Q})$ minus cash revenues $(\mathrm{R})$.

The estimate for the cost of domestic use of energy covers excess losses ${ }^{5}$ and domestic consumption valued at cost-recovery tariffs. ${ }^{6}$ Revenues are estimated by multiplying domestic consumption by actual tariffs as adjusted for the (cash) bill collection rate. Formally:

(1) $\mathrm{QFD}=\mathrm{Q}-\mathrm{R}$

\footnotetext{
${ }^{3}$ Petri et al. (2002).

${ }^{4}$ Total losses are divided into "normative" and "excess" losses. Normative losses are technical waste of production owing to conversion leakages of generation and transmission to distribution. Excess losses occur because of poor maintenance and lack of replacement investment (excess technical losses) as well as inadequate metering and billing practices, or outright theft (commercial losses).

${ }^{5}$ Normative losses are taken into account by including this cost component in the cost-recovery tariff estimate.

${ }^{6}$ If energy is exported at below cost-recovery prices, payments are in arrears, and excess losses occur owing to poor billing or leakages in the transmission process; using domestic consumption as a yardstick underestimates the true level of quasi-fiscal deficits. The difference represents a net resource transfer abroad.
} 
(2) $\mathrm{Q}=1 /(1-\ell) *(\mathrm{Ch}+\mathrm{Ci}+\mathrm{Co}) * \mathrm{APC}$

(3) $\mathrm{R}=(\mathrm{Ch}+\mathrm{Ci}+\mathrm{Co}) * \mathrm{~T} * \mathrm{Ccash}$

where $\mathrm{Q}=$ cost of domestic production for households, industry, and other domestic users;

$\mathrm{R}=$ cash revenue from households, industry, and other domestic users;

$\ell=$ average annual excess loss rate;

$\mathrm{Ch}=$ household consumption;

$\mathrm{Ci}=$ industrial consumption;

$\mathrm{Co}=$ consumption by other domestic users;

$\mathrm{APC}=$ average cost of production per $\mathrm{kWh}$;

$\mathrm{T}=$ average actual tariff for households, industry, and others;

Ccash $=$ cash collection ratio for households, industry, and others.

The cost-recovery tariff is measured as the average cost of production (APC), as estimated by World Bank staff. ${ }^{7}$ The APC reflects the cost of a sustained electricity and gas supply when necessary maintenance and replacement of depreciated capital is taken into account. The cost of future capacity expansion is not included in the APC. Therefore, APC provides only the lower benchmark for tariff policy and is below the long-run marginal cost (LRMC).

The quasi-fiscal deficits in Table 1 are computed following the end-product approach and reflect the countries' variable record in tariff policies, bill collection practices, and loss prevention. ${ }^{8}$ In 2002, the QFDs in the sample countries' electricity and gas sectors varied between $1 / 2$ percent of GDP in Armenia to 23-27 percent in Tajikistan and Uzbekistan, respectively. QFDs were typically much larger in electricity than in gas sectors, the latter being significantly smaller in size compared with the electricity sector. Only Uzbekistan recorded a higher gas sector QFD. In Tajikistan, electricity contributed over 20 percent of GDP to the quasi-fiscal deficit, largely reflecting the underpricing of power for the large state-owned aluminum smelter, TADAZ.

\footnotetext{
${ }^{7}$ In measuring the APC, the market value of energy inputs of production (such as heavy fuel, natural gas, etc.) is estimated as the opportunity cost of alternative use of these inputs (export prices, sales price to the private sector, or world market import prices).

${ }^{8}$ While the above methodology is applied to all countries in the sample, possible differences in the source data may limit a full cross-country comparability. More importantly, these estimates may differ from those used in other IMF documents, because source data as well as methodology in the latter may differ.
} 
These QFD estimates suggest that the general government overall fiscal balance is not an accurate indicator of fiscal soundness in these CIS countries. With the exception of Armenia, quasi-fiscal deficits were significantly larger than actual government fiscal deficits

(Figure 1). Uzbekistan and Tajikistan not only had the highest QFDs, but were also the only countries where QFDs increased in 2000-02. Only in Armenia, the extended fiscal deficitthe general government fiscal balance plus the QFD - remained below 5 percent of GDP in 2002. Such extended deficits were close to 25 percent of GDP in Tajikistan and Uzbekistan, and about 17 percent in the Kyrgyz Republic in 2002. Admittedly, adding up these two deficit without netting out mutual transfers is double counting thus exaggerating the size of such an extended fiscal balance. However, typically the explicit net transfer is small in these countries just because of the existence of the large implicit subsidy schemes.

Table 1. Quasi-Fiscal Deficits in Electricity and Gas Sectors in 2002

(In percent of GDP)

\begin{tabular}{lccc}
\hline & & \multicolumn{2}{c}{ Of which: } \\
\cline { 3 - 4 } & Quasi-Fiscal Deficit & Electricity Sector & Gas Sector \\
\hline Country: & & & -0.5 \\
Armenia & 0.6 & 1.1 & 1.8 \\
Azerbaijan & 11.6 & 9.8 & 0.2 \\
Georgia & 5.7 & 5.5 & 0.2 \\
Kyrgyz Republic & 12.2 & 12.0 & 0.9 \\
Moldova & 4.2 & 3.3 & 1.3 \\
Tajikistan & 22.7 & 21.4 & 3.1 \\
Ukraine & 8.4 & 5.3 & 10.7 \\
Uzbekistan & 26.6 & 15.9 &
\end{tabular}

Source: Authors' estimates.

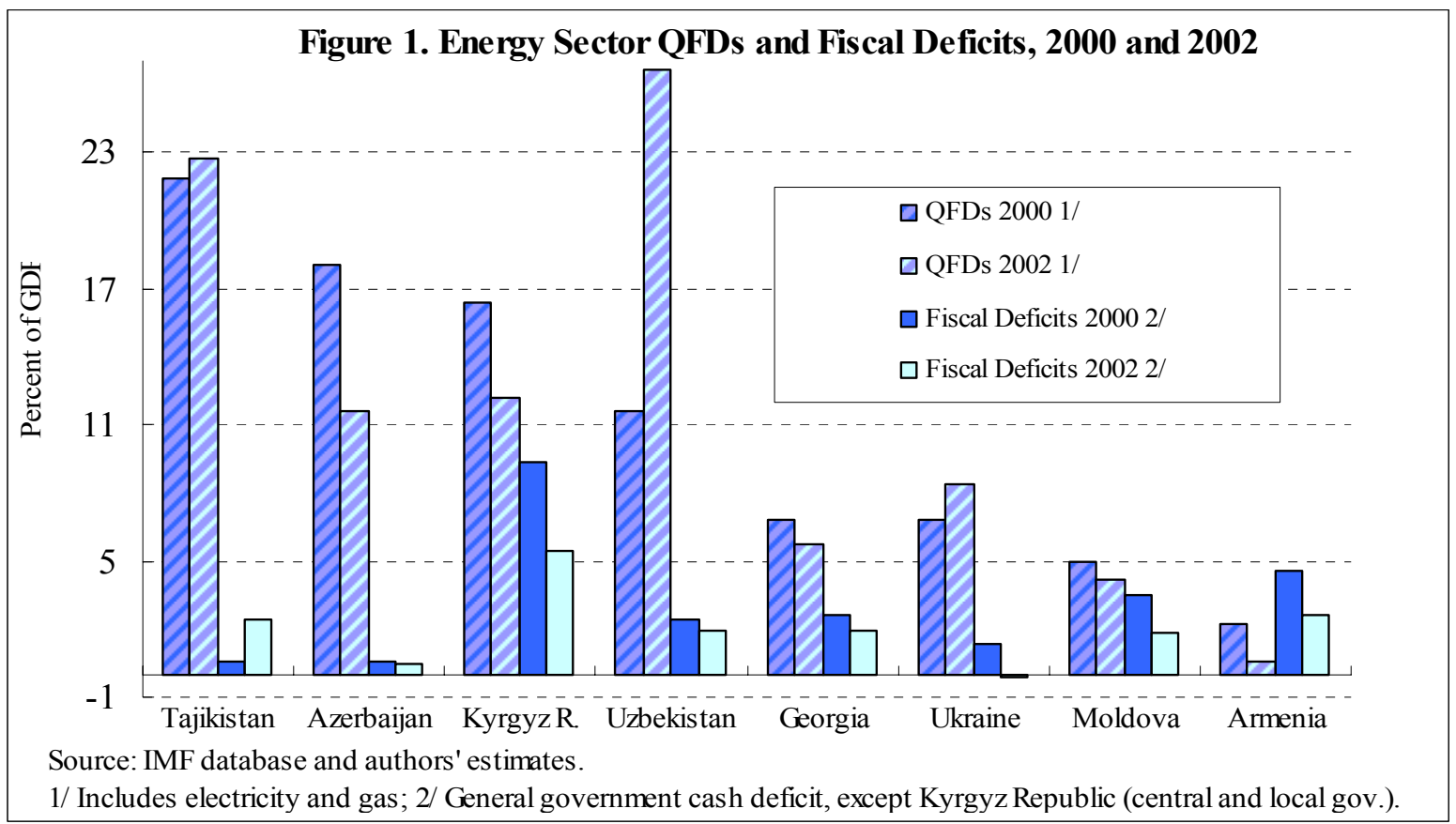




\section{Electricity}

The computation model allows for a breakdown of the QFD to three components: mispricing, cash collection, and losses. Actual tariffs varied significantly across countries in 2002 (Table 2) being the lowest in Tajikistan and the Kyrgyz Republic - the two countries with abundant hydro-power resources where also APCs were the lowest. Nevertheless, their costrecovery ratios - together with Uzbekistan and Azerbaijan - remained well below those in other countries in the sample.

Table 2. Quasi-Fiscal Deficit Indicators of the Electricity Sector in 2002

\begin{tabular}{lcccccc}
\hline & $\begin{array}{c}\text { QFD } \\
(\% \text { of GDP) }\end{array}$ & $\begin{array}{c}\text { Actual } \\
\text { Tariff } \\
(\text { UScts/kWh) }\end{array}$ & $\begin{array}{c}\text { Cost Recovery } \\
\text { Tariff } 1 / \\
(\text { UScts/kWh) }\end{array}$ & $\begin{array}{c}\text { Cash } \\
\text { Collection } \\
(\% \text { of Bill) }\end{array}$ & $\begin{array}{c}\text { Excess } \\
\text { Losses 2/ } \\
(\% \text { of Prod.) }\end{array}$ & $\begin{array}{c}\text { Cost } \\
\text { Recovery 3/ } \\
(\%)\end{array}$ \\
\hline Armenia & 1.1 & 3.7 & 3.7 & 90 & 10 & 81.6 \\
Azerbaijan & 9.8 & 2.3 & 3.8 & 30 & 5 & 17.2 \\
Georgia & 5.5 & 4.1 & 4.1 & 35 & 5 & 33.3 \\
Kyrgyz Republic & 12.0 & 1.2 & 2.3 & 33 & 35 & 11.1 \\
Moldova & 3.3 & 5.0 & 5.0 & 75 & 19 & 61.0 \\
Tajikistan & 21.4 & 0.4 & 2.1 & 86 & 5 & 13.9 \\
Ukraine & 5.3 & 3.1 & 4.0 & 87 & 13 & 58.8 \\
Uzbekistan & 15.9 & 1.0 & 3.5 & 50 & 18 & 12.3 \\
\hline
\end{tabular}

Source: Authors' estimates.

1/ Estimates provided by World Bank staff.

2/ Technical and commercial losses above the normative level.

3/ Revenue collection in percent of market cost.

Highest tariffs were charged in Moldova where also production costs of electricity was high in part reflecting a significant share of imported gas as an input to power generation. ${ }^{9}$

Payment collection (in cash) was reported to be as high as 90 percent in Armenia, Tajikistan, and Ukraine but in Azerbaijan, Georgia, and the Kyrgyz Republic only one-third of electricity billing was actually collected. Excess technical and commercial losses appear to be most severe in the Kyrgyz Republic, Moldova, and Uzbekistan. ${ }^{10}$ Except for Armenia and Georgia, residential tariffs were cross-subsidized by higher industrial tariffs (Table 3). ${ }^{11}$

\footnotetext{
${ }^{9}$ Gas as a source of electricity was 94 percent in Moldova. The U.S. Nuclear Energy Institute estimates that electricity produced by gas costs 4.1 U.S. cents per kilowat hour, compared with 1.7 cents for nuclear power. See http://www.nei.org.

${ }^{10}$ As the cash collection rate is measured relative to billing, weakness in billing coverage (including poor metering, meter tinkering, and theft) are reflected in the excess loss rates.

11 Typically, the cost of delivering power to industry is lower than that to households because of the economies of scale.
} 
Table 3. Electricity Tariff Cross-Subsidization, 2002

\begin{tabular}{lcccc}
\hline & \multicolumn{4}{c}{ Actual Tariffs } \\
\cline { 2 - 5 } & Households & Industry & Other & Average \\
\cline { 2 - 5 } Armenia & 4.3 & 3.1 & 3.6 & 3.7 \\
Azerbaijan & 2.0 & 3.3 & 2.3 & 2.3 \\
Georgia & 5.5 & 2.2 & 3.2 & 4.1 \\
Kyrgyz R. & 0.9 & 1.7 & 1.2 & 1.2 \\
Moldova & na & na & na & 5.0 \\
Tajikistan & 0.1 & 0.6 & 0.2 & 0.4 \\
Ukraine & 2.6 & 3.0 & 3.6 & 3.1 \\
Uzbekistan & na & na & na & 1.0 \\
\hline
\end{tabular}

Source: IMF country desk data.

In high-deficit countries (Tajikistan and Uzbekistan), the main contribution to the electricity QFD was mispricing. In the Kyrgyz Republic, losses were exceptionally high and in Georgia, where tariffs were at cost recovery levels, bill collection remained low.

Table 4. Contributions to the Electricity QFD in 2002 1/ (In percent of GDP)

\begin{tabular}{lcccc}
\hline & Total QFD & \multicolumn{3}{c}{ Contributions: } \\
\cline { 3 - 5 } & & Underpricing & Non-payment & Losses \\
\hline Armenia & 1.1 & 0.0 & 0.5 & 0.6 \\
Azerbaijan & 9.8 & 4.4 & 4.8 & 0.5 \\
Georgia & 5.5 & 0.0 & 5.1 & 0.4 \\
Kyrgyz Republic & 12.0 & 4.2 & 3.1 & 4.7 \\
Moldova & 3.3 & 0.0 & 1.7 & 1.6 \\
Tajikistan & 21.4 & 19.6 & 0.6 & 1.2 \\
Ukraine & 5.3 & 2.5 & 1.1 & 1.7 \\
Uzbekistan & 15.9 & 10.4 & 2.2 & 3.3 \\
\hline
\end{tabular}

Source: Authors' estimates.

1/ Based on Table 2.

\section{Gas}

In gas-producing countries-Azerbaijan and Uzbekistan-actual gas tariffs were below extraction costs "at the well" plus transmission and distribution fees (Table 5). Also in Ukraine and Tajikistan actual tariffs remained below cost-recovery levels while in Armenia, Georgia, Moldova, and the Kyrgyz Republic tariffs fully covered costs in 2002. Cash collections for gas were generally higher than for electricity, between 50 and 90 percent of 
the billing. As in electricity, excess losses in the gas sector were highest in the Kyrgyz Republic.

Table 5. Quasi-Fiscal Deficit Indicators of the Gas Sector in 2002

\begin{tabular}{|c|c|c|c|c|c|c|c|}
\hline & $\begin{array}{c}\text { QFD } \\
\text { (\% of GDP) }\end{array}$ & $\begin{array}{l}\text { Actual Tariff } \\
\text { (US\$ } 1000\end{array}$ & $\begin{array}{c}\text { Cost Recovery } \\
\text { Tariff } 1 / \\
\text { (US\$/1000 }\end{array}$ & $\begin{array}{l}\text { Of which: } \\
\text { Gas Import } \\
\text { Price } \\
\text { (US } \$ / 1000\end{array}$ & $\begin{array}{c}\text { Cash } \\
\text { Collection } \\
(\% \text { of Bill) }\end{array}$ & $\begin{array}{c}\text { Excess } \\
\text { Losses } 2 / \\
\text { (\% of Prod.) }\end{array}$ & $\begin{array}{c}\text { Cost } \\
\text { Recovery 3/ } \\
(\%)\end{array}$ \\
\hline Armenia & -0.5 & 80.0 & 58.0 & 55.0 & 91 & 6 & 118.8 \\
\hline Azerbaijan & 1.8 & 15.0 & 30.0 & -- & 47 & 15 & 20.0 \\
\hline Georgia & 0.2 & 105.0 & 70.0 & 65.0 & 67 & 12 & 89.0 \\
\hline Kyrgyz Republic & 0.2 & 77.1 & 65.5 & 46.3 & 98 & 26 & 84.5 \\
\hline Moldova & 0.9 & 66.8 & 65.0 & 60.0 & 78 & 2 & 78.8 \\
\hline Tajikistan & 1.3 & 57.9 & 63.7 & 48.4 & 55 & 5 & 47.5 \\
\hline Ukraine & 3.1 & 44.1 & 62.5 & 51.6 & 89 & 5 & 59.6 \\
\hline Uzbekistan & 10.7 & 11.1 & 25.0 & -- & 50 & 7 & 20.6 \\
\hline
\end{tabular}

Source: Authors' estimates.

1/ Estimates provided by World Bank staff.

2/ Technical and commercial losses above the normative level.

3 / Revenue collection in percent of market cost.

Table 6 suggests that mispricing is a smaller problem in the gas sector than in the electricity sector. In several countries gas tariffs were reported to be even above the cost recovery levels. Also, payment discipline and loss prevention appear to be better than in the electricity sector.

Table 6. Contributions to the Gas QFD in 2002 1/

(In percent of GDP)

\begin{tabular}{lcccc}
\hline & Total QFD & & \multicolumn{3}{c}{ Contributions: } & \\
\cline { 3 - 5 } & & Underpricing & Non-payment & Losses \\
\hline Armenia & -0.5 & -0.9 & 0.3 & 0.1 \\
Azerbaijan & 1.8 & 0.9 & 0.5 & 0.3 \\
Georgia & 0.2 & -0.7 & 0.7 & 0.2 \\
Kyrgyz Republic & 0.2 & -0.2 & 0.0 & 0.4 \\
Moldova & 0.9 & -0.1 & 0.9 & 0.1 \\
Tajikistan & 1.3 & 0.2 & 1.0 & 0.1 \\
Ukraine & 3.1 & 2.1 & 0.6 & 0.4 \\
Uzbekistan & 10.7 & 7.0 & 2.8 & 0.9 \\
\hline
\end{tabular}

Source: Authors' estimates.

1/ Based on Table 5. 


\section{Macroeconomic Relevance OF Quasi-Fiscal Deficits}

Quasi-fiscal deficits have several negative macroeconomic and structural implications. In particular, high QFDs in the energy sectors of CIS and Central and East European (CEE) transition countries appear to be closely linked with high energy inefficiencies as measured by the use of energy per unit of GDP (Figures 2 and 3). ${ }^{12}$ These, inefficiencies, in turn, are detrimental to growth as they undermine total factor productivity.
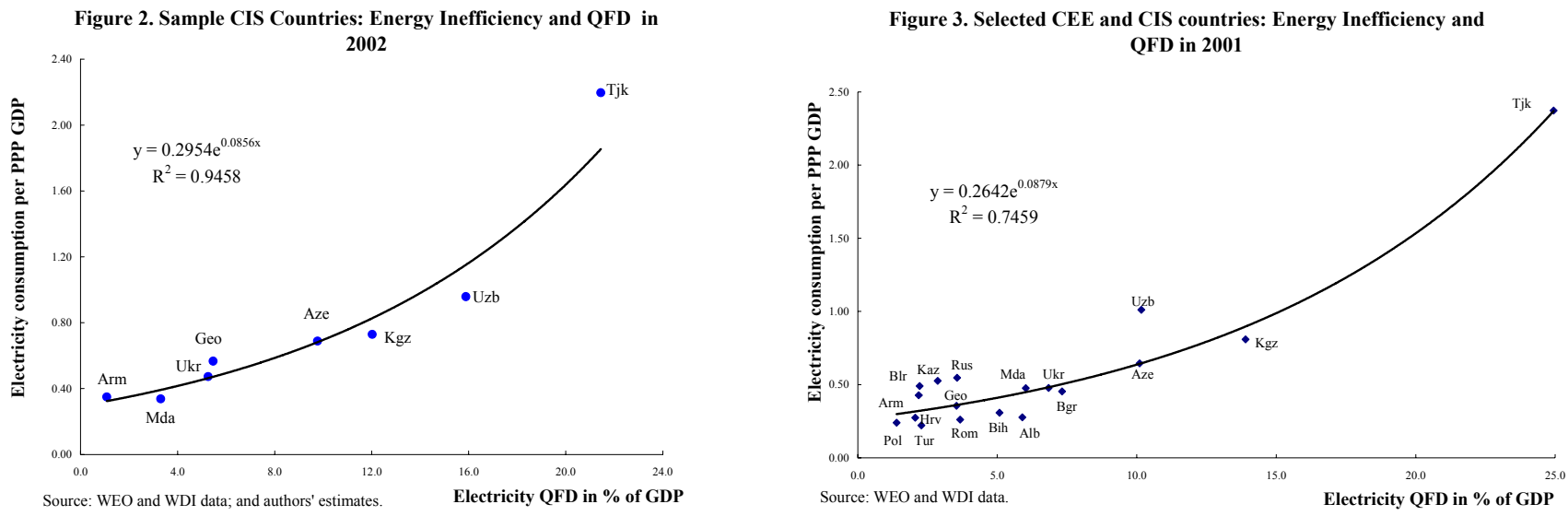

In addition, QFDs are detrimental to macroeconomic stability because of unsound deficit financing policies.

Quasi-fiscal deficits have adverse effects on growth and macroeconomic stability through several channels. They

- undermine financial discipline in government agencies and households thus weakening the effectiveness of fiscal policy and narrowing the fiscal space;

- $\quad$ keep nonviable enterprises afloat thus delaying enterprise restructuring and undermining economy-wide productivity growth;

- $\quad$ distort relative prices thus reducing incentives to save energy;

- distort resource allocation by locking resources in energy and capital intensive production thus crowding out labor intensive small and medium-size enterprises;

${ }^{12}$ The functional form of the regression line in these figures (and others in the paper) was chosen on the basis of the explanatory power of the regression equation. 
- $\quad$ increase energy-importing countries' external vulnerability by creating a wedge between domestic and international prices. ${ }^{13}$

- distort the size of the government in the economy.

The financing of quasi-fiscal deficits adds to macroeconomic imbalances. The common financing pattern of energy companies' financial imbalances consists of budgetary transfers, wage arrears, arrears to domestic input suppliers, external arrears, and capital depreciation. Eventually, a failure to eliminate quasi-fiscal deficits will lead to a gradual decay of the capital stock and increasing supply shortages. Even if the power sector was too large in Soviet times, frequent supply disruptions in most countries of the sample suggest that the effective capacity of power generation may have already shrunk below the optimal level.

Quasi-fiscal deficits are also a source of weak public expenditure management and poor governance. Where quasi-fiscal deficits are financed through direct budget subsidies to cover energy companies' losses or through non-targeted transfers to households as income support, other expenditures, including wages, social spending, and public investment, are compressed. At the same time, budgetary arrears to energy companies lead to nontransparent budgetary offset operations as energy companies' tax liabilities are written off against government energy bills.

\section{ENERGY SECTOR CONDITIONALITY}

Conditionality on the energy sector performance was included in the IMF financial arrangements with the CIS countries early in the transition process. Program conditionality mainly covered the electricity sector but measures dealing with the gas sector were also important, especially in Ukraine, Moldova, and Tajikistan. In principle, the World Bank had the lead in designing energy sector reforms in the region and the Fund's role was expected to be mainly supportive. During the 1990s, the Bank's strategy was to promote the restructuring of the energy sector by unbundling vertically integrated monopolies for privatization, improving the regulatory framework, and addressing the demand side through tariff and billing reforms. Specifically, the 1998 reform strategy of the World Bank's Europe and Central Asia Department (ECA) for the energy sector consisted of the following five steps:

- selling assets to private strategic investors;

- establishing predictable and transparent regulations;

- raising tariffs to cost-recovery levels;

- expanding metering and cutting off nonpaying customers; and

- introducing competition to generation, transmission, and distribution networks.

In practice, the division of labor between the Fund and the Bank was less clear. IMFsupported programs covered conditionality on increasing tariffs, strengthening payments

${ }^{13}$ The energy-related external debt has been a significant problem in Armenia, Moldova, Georgia, and Ukraine. 
discipline, improving the overall energy sector financial balance, and eliminating energy use privileges. But Fund-supported programs also applied conditionality on privatization and regulation.

\section{A. IMF Conditionality on Electricity and Gas}

Overall, 155 performance criteria, structural benchmarks, and prior actions were imposed for the eight countries in the sample in 1993-2003. The intensity of conditionality peaked in 1998 and 1999 (Figure 4). During the peak period, Ukraine accounted for more than half of the number of conditions. In 2001-03, the volume of conditions fell to less than half of that in the peak years, mainly on account of downscaling in Ukraine. Only in Georgia and Tajikistan there was more conditionality in 2002-03 than in previous years (see Appendix I, Tables 1 and 5).

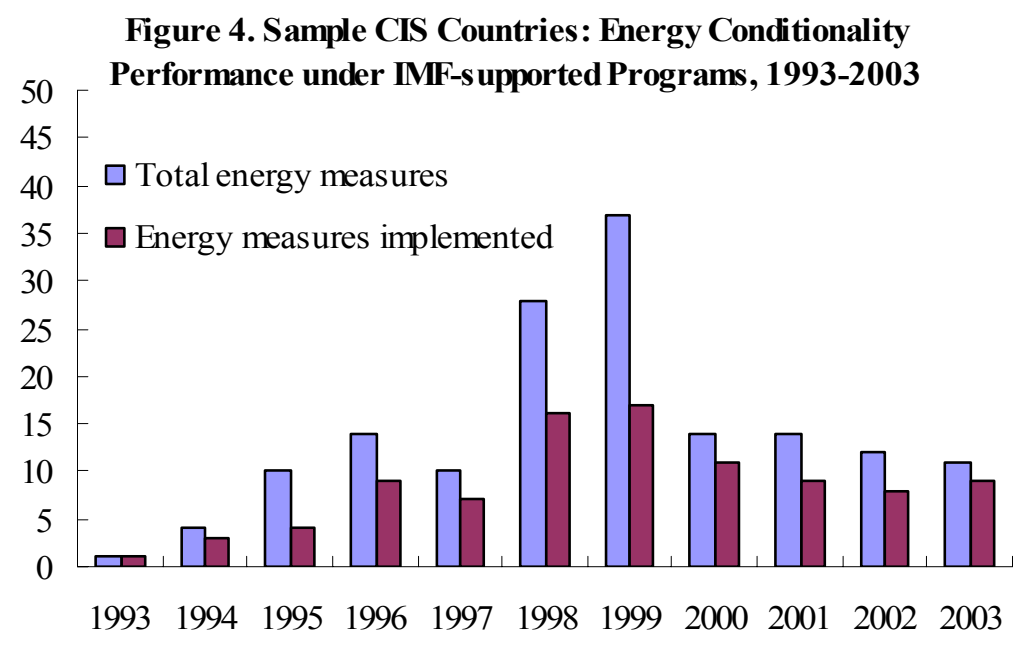

Source: Authors' estimates.

Because quasi-fiscal deficits remained large, the decline in conditionality cannot be explained by reduced macroeconomic relevance of these measures. One reason was increased recognition of the complexity of energy sector reforms. A comprehensive approach was considered useful, but programs with extensive policy matrices were difficult to monitor and many important measures fell outside the Fund's core expertise. At the same time, many measures were dropped because they became part of the World Bank conditionality. The new streamlining guidelines of Fund structural conditionality issued in 2001 recognized these developments and Fund conditionality was applied more parsimoniously thereafter.

More generally, there were increasing doubts that a large number of structural conditions was effective. Indeed, there appears to be some cross-country evidence from the sample that with the number of conditionality increasing, the marginal rate of compliance declines

(Figure 5). ${ }^{14}$ On aggregate, the conditionality in 1998-2000 covered 79 measures, more than

\footnotetext{
${ }^{14}$ Such relationship is significant also if Ukraine is excluded from the sample.
} 
twice as many as in 2001-2003 (37 measures). The rate of compliance, however, was only 55 percent compared to 70 percent in 2001-03.

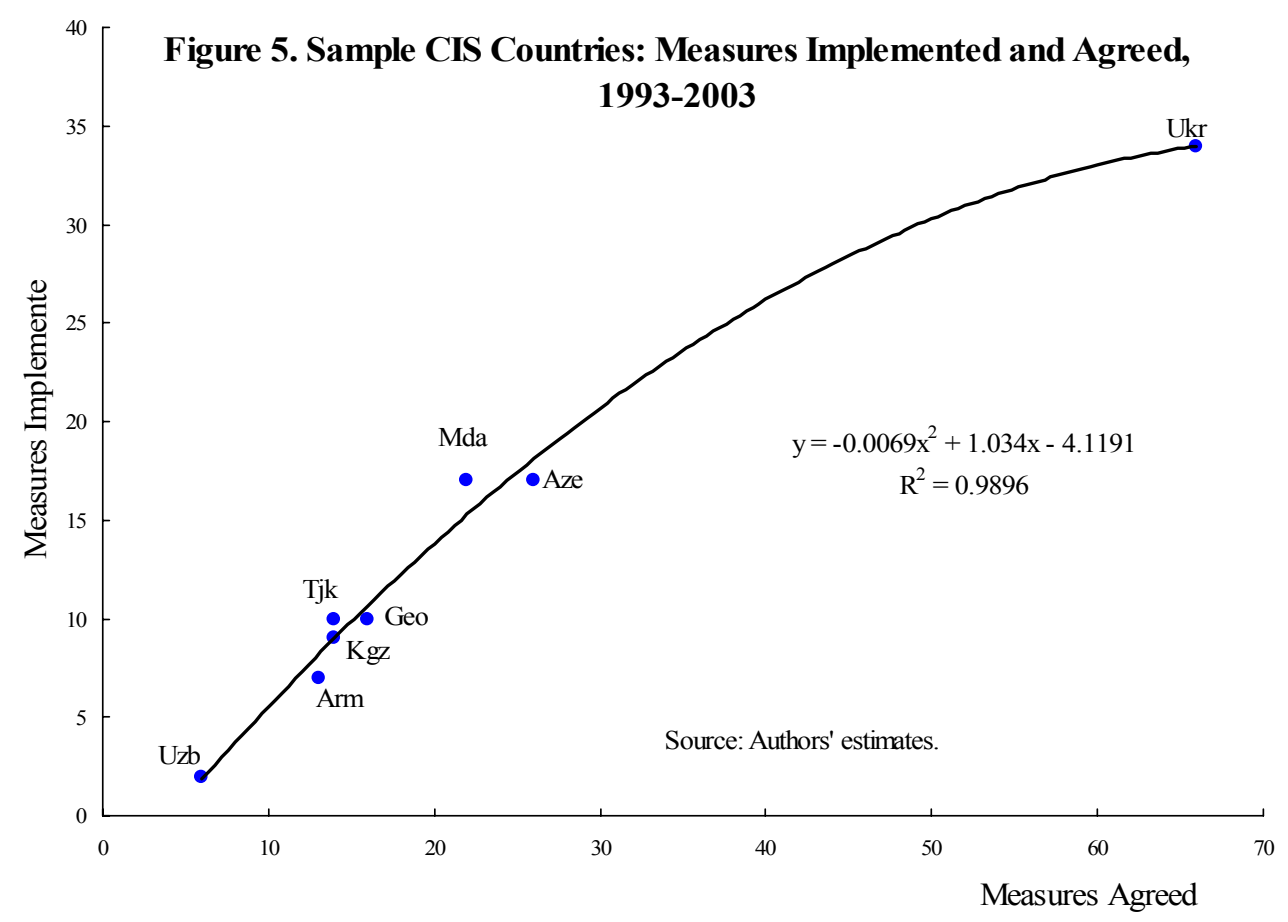

More than half of Fund conditionality addressed financial imbalances indirectly through measures on tariffs, discounts, arrears, and bill collection (80 measures) (Figure 6). Another large group of measures emphasized privatization and restructuring ( 33 measures). The measures addressing directly the energy sector's financial balances (16 measures) were less numerous. Measures on the reduction of external energy debt were applied to Moldova, Ukraine, and Georgia.

Figure 6. Sample CIS Countries: Energy Conditionality By Type of Measure, 1993-2003

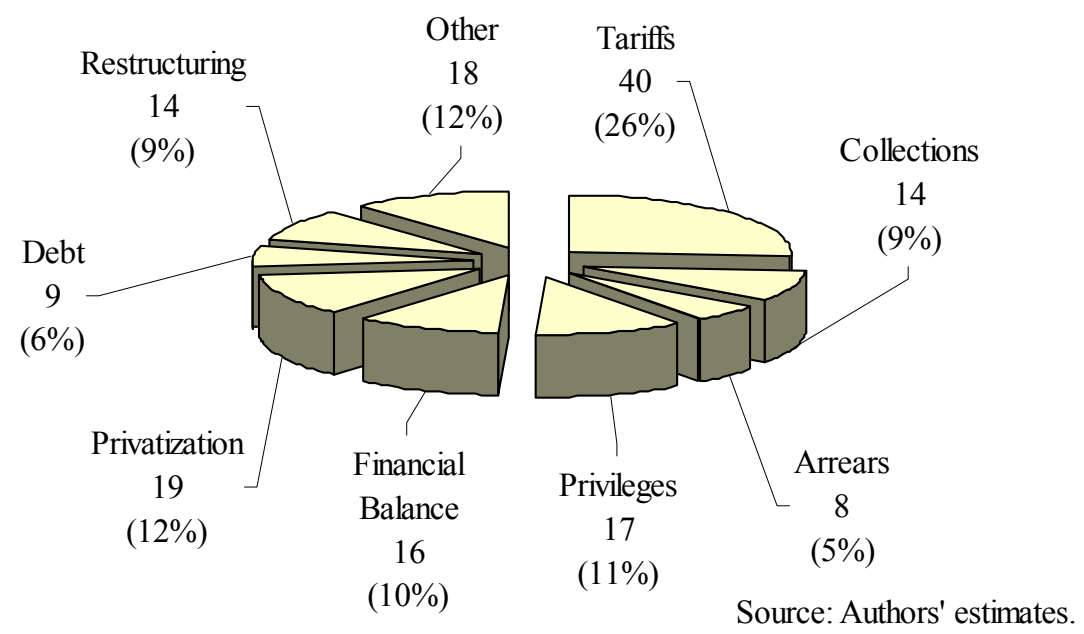


The conditionality agreed with Ukraine was the most comprehensive. Sixty percent of measures applied to cost recovery, one-fifth addressed privatization, regulation, and sector restructuring. Some countries had a rather limited number of measures. Armenia, Georgia, and Tajikistan focused on narrower conditionality, mainly on tariffs, bill collection, and energy use privileges. In Azerbaijan the majority of measures was on pricing and transparency. Also in the Kyrgyz Republic the earlier extensive conditionality declined after 2000, largely because a new World Bank energy sector program was introduced.

\section{B. Performance Record}

The aggregate compliance rate under Fund conditionality was 61 percent in 1993-2003. However, there was a wide variation across countries and measures (Tables 7 and 8). The sample data do not suggest any significant correlation between the compliance rate and QFD. Although in Moldova the high compliance rate concurred with relatively low QFD, Tajikistan was left a large QFD in 2002 despite a high compliance. Armenia had the second lowest compliance rate but one of the lowest energy sector deficits. Uzbekistan had the smallest number of conditionalities (all under the 1995-96 Systemic Transformation Facility (STF) program) but it implemented none of the measures. Ukraine's compliance rate was about 50 percent, but it implemented 3 to 4 times as many measures as most other countries. Nevertheless, its QFD remained high in early 2000s. By type of measures, compliance was lowest in bill collection and tariffs - the most sensitive areas politically. The lack of significant correlation between the compliance rate and the QFD outcomes casts doubts about the appropriateness of the conditionality design, although it may also reflect the absence of the critical mass of reform measures.

Table 7. Sample CIS Countries: Overall Compliance Per Country, 1993-2003

\begin{tabular}{lccc} 
& \multicolumn{2}{c}{$1993-2003$} & \\
\cline { 2 - 3 } & total & $\begin{array}{c}\text { implem- } \\
\text { ented }\end{array}$ & $\begin{array}{c}\text { Compli- } \\
\text { ance rate }\end{array}$ \\
\hline Azerbaijan & 13 & 9 & $69 \%$ \\
Armenia & 12 & 6 & $50 \%$ \\
Georgia & 16 & 10 & $63 \%$ \\
Kyrgyz Republic & 15 & 10 & $67 \%$ \\
Tajikistan & 13 & 9 & $69 \%$ \\
Moldova & 20 & 17 & $85 \%$ \\
Ukraine & 63 & 33 & $52 \%$ \\
Uzbekistan & 3 & 0 & $0 \%$ \\
& & & \\
\hline Total & 155 & 94 & $61 \%$ \\
Total excl. Ukraine & 92 & 61 & $66 \%$
\end{tabular}

Source: Authors' estimates
Table 8. Sample CIS Countries: Overall Compliance Per Measure, 1993-2003

\begin{tabular}{|c|c|c|c|}
\hline & \multicolumn{2}{|c|}{ 1993-2003 } & \multirow[b]{2}{*}{$\begin{array}{l}\text { Compli- } \\
\text { ance rate }\end{array}$} \\
\hline & total & $\begin{array}{c}\text { implem- } \\
\text { ented }\end{array}$ & \\
\hline Tariffs & 40 & 20 & $50 \%$ \\
\hline Bill collection & 14 & 5 & $36 \%$ \\
\hline No arrears & 8 & 5 & $63 \%$ \\
\hline Reduce energy privileges & 17 & 10 & $59 \%$ \\
\hline Financial balance & 16 & 12 & $75 \%$ \\
\hline Privatization & 19 & 12 & $63 \%$ \\
\hline Foreign energy debt & 9 & 9 & $100 \%$ \\
\hline Regulation, restructuring & 14 & 10 & $71 \%$ \\
\hline Other & 18 & 11 & $61 \%$ \\
\hline Total & 155 & 94 & $61 \%$ \\
\hline
\end{tabular}




\section{Financial balance was seldom addressed}

Only few programs addressed the energy sector financial balance directly. In Armenia, such a balance was subject to quarterly ceilings in 1996-2001. However, the deficits were difficult to measure, control, and forecast because of nontransparency of subsidies and exogenous factors, such as changes in weather and consumption patterns. As a result, the program's performance criterion was downgraded to an indicative target in 2002. In Moldova, only a non-quantified commitment to improve financial performance was a program benchmark in 1996. The 2001 Poverty Reduction and Growth Facility (PRGF) program of the Kyrgyz Republic set the monitoring of the quasi-fiscal deficit of the energy sector under a review clause, and performance was measured through a scheduled tariff increase in $2002 .{ }^{15}$ The 2003 program included a structural benchmark on a semi-annual reporting and an indicative target for the QFD. ${ }^{16}$

\section{Tariff targets were common}

About 25 percent of all measures subject to energy conditionality addressed tariffs but only half of them were implemented. The focus on tariffs is not surprising because they are easy to measure and monitor. Also, energy inefficiencies appear to be closely associated with distorted energy pricing (Figure 7). Nevertheless, in most CIS countries residential electricity tariffs were still below the other transition countries' average in 2003. In extreme cases, the residential tariffs (Central Asia) should be raised tenfold to reach the average tariff level in Central Europe.

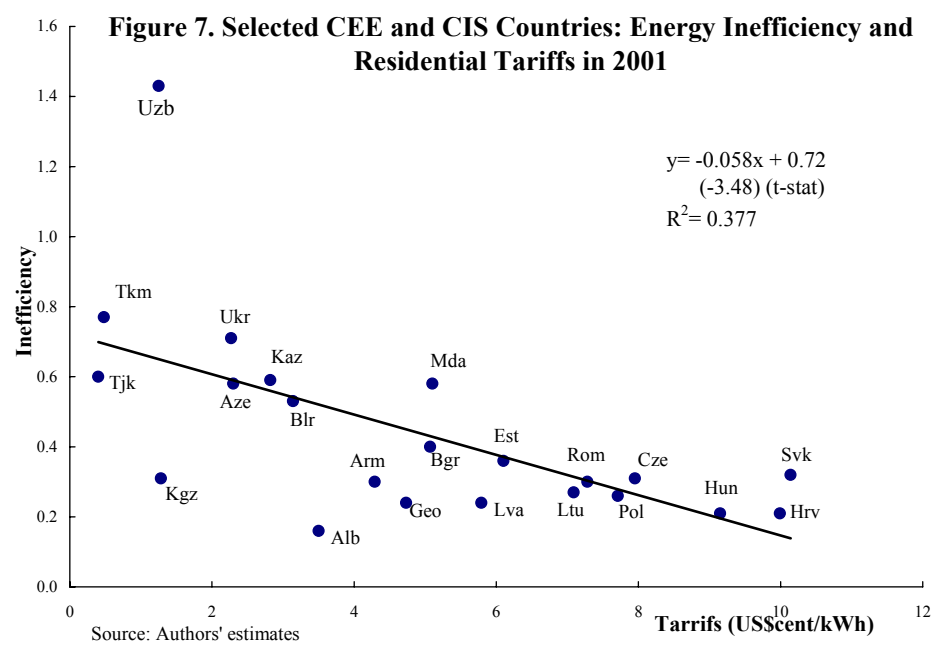

${ }^{15}$ Electricity tariffs were increased by 20 percent on April 1, 2002.

${ }^{16}$ The electricity sector QFD was programmed to decline from 12 percent of GDP in 2002 to 11 percent in 2003, which was achieved. 
Despite political sensitivities, the tariff policy appears to be the most effective tool to address the QFD problem. Regressing electricity tariffs and cost-recovery ratios against QFD in the sample countries suggests that low tariffs correlate strongly with high QFDs (Figures 8 and 9). By 2002, however, only Armenia, Georgia, and Moldova had raised their electricity tariffs to cost recovery levels. Others, in particular the Kyrgyz Republic and Tajikistan, still had a long way to go. Although Armenia's tariff conditionality was not observed during the 1995-96 STF and Stand-By Arrangement (SBA) programs, under the 1996 Enhanced Structural Adjustment Facility (ESAF) program, residential and industrial tariffs were raised to cost recovery levels. In Georgia an increase and unification of household and industrial electricity tariffs was implemented as a structural benchmark in 1997, but subsequently, these tariffs deviated. Two other benchmarks aiming at an improved tariff structure by end-1998 were first delayed, then dropped from the Fund-supported program. They were implemented under World Bank conditionality in 2001. Under the 1998 Fund-supported program, Georgia also introduced a surcharge on electricity tariffs to reduce energy-related external debt. The legislation was passed as a prior action, but the surcharge was not carried out as a later structural benchmark. In Moldova, adding a debt surcharge to energy costs was the basis for tariff increases that were implemented in 1996 and 1998. Subsequent tariff increases were introduced under World Bank conditionality.
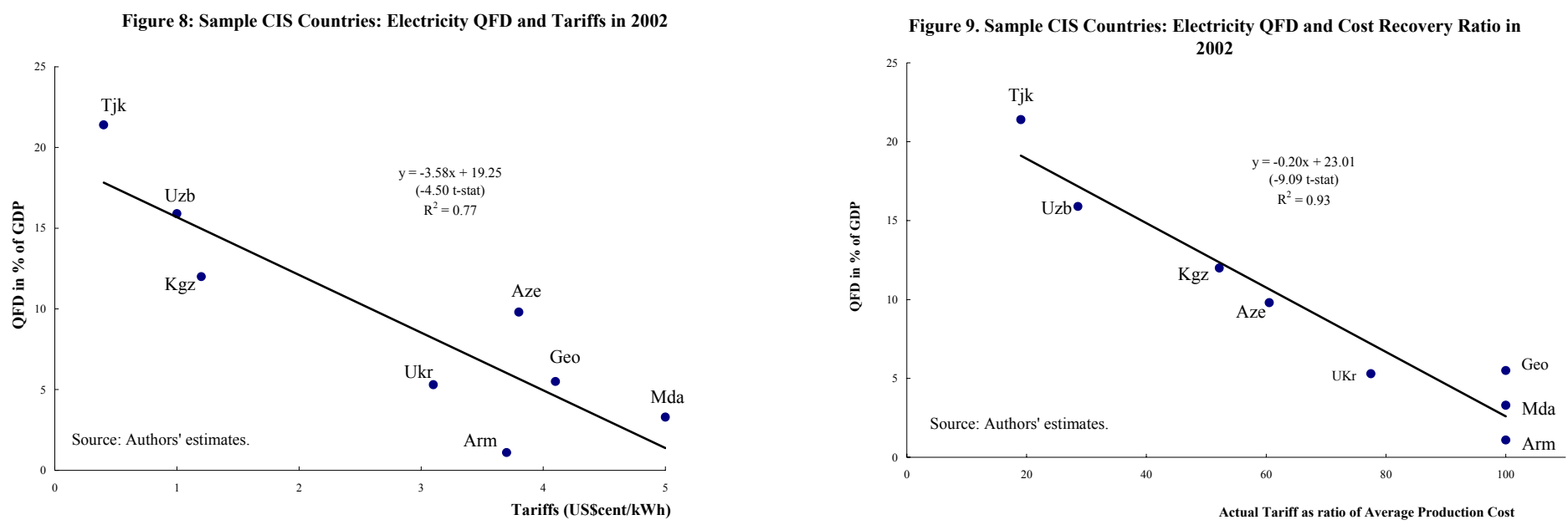

In the Kyrgyz Republic a prior action on the increase of power tariffs was observed in early 2000. Under the pressure from the Fund and the World Bank - but without formal conditionality - further tariff increases were implemented in 2002 despite strong political resistance. Tariff reform in Ukraine also faced opposition, especially in the early program years, and many performance criteria were missed. By 2002, however, the situation had improved as many enterprises had become profitable and paid higher tariffs. In Tajikistan, household tariffs were raised in 1998, but the exchange rate depreciation after the 1998 Russian crisis largely eroded the gains in cost recovery, as happened in many other CIS countries as well. In 2000, the scheduled electricity tariff increases were not implemented while in 2002 gas tariffs were increased. At that time, a commitment was given to periodically adjust all utility tariffs. 


\section{Bill collection and losses were problematic}

In contrast to tariffs, bill collection rates and excess losses do not seem to correlate significantly with QFDs (Figures 10 and 11). In Tajikistan, the bill collection rate was reported at 86 percent in the electricity sector in 2002 but because of the very low tariffs, the QFD remained the highest among the comparator countries. In Georgia, the collection rate was only 35 percent but tariffs were high which was reflected in only a moderate QFD. Similarly, low reported losses do not necessarily imply low QFDs as evidenced by data on Tajikistan, Azerbaijan, and Uzbekistan.
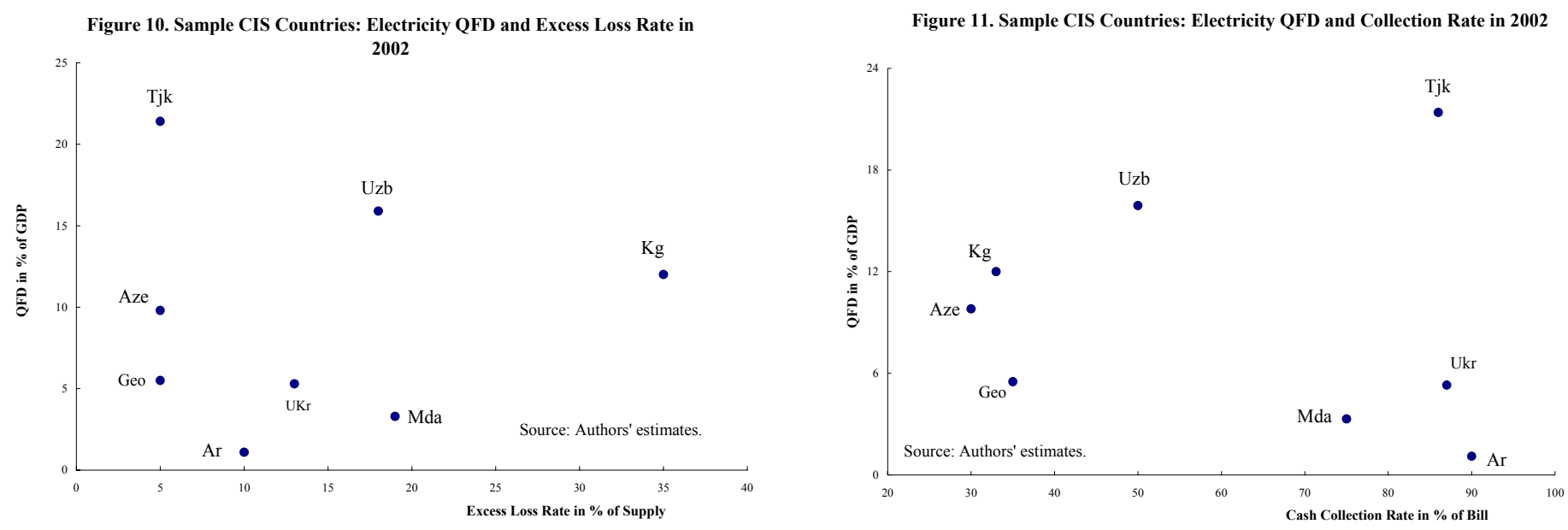

Under Fund conditionality, measures on bill collection often failed. In the sample, the average compliance rate during 1993-2003 was only 36 percent - a piece of evidence of the widespread tolerance on the nonpayment culture in the CIS in the 1990s. The 1995 program of Georgia contained a structural benchmark to raise electricity bill collections to 60 percent of sales, but this target was not achieved. The measure (at 70 percent collection rate) was reintroduced in the 2002 program but again without success. In Armenia, a policy of cutting off nonpaying customers was successfully introduced in 1996 contributing to higher collection rates. Also in Ukraine, collection rates improved in 2000, after a strong cut-off policy was put in place. In Tajikistan the mid-2002 gas bill collection target was observed but in 2003 such a target was dropped and replaced by other energy sector reform measures. The programs of the Kyrgyz Republic and Moldova did not have conditionality on bill collections. No program included specific conditionality on loss prevention.

\section{Energy use privileges were difficult to eliminate}

Removing tariff discounts has been politically difficult as large segments of population inherited these privileges from the Soviet era. Abolishing such privileges was also technically challenging as poor households continued to need social protection but privileges had been granted on categorical basis without means testing. Although Armenia removed such categorical privileges for heating and hot water in 1995, a benchmark to convert 
exemptions on electricity payments to explicit income support failed in 1996. In the Kyrgyz Republic, a benchmark to replace privileges with direct budgetary transfers to low-income households failed in 1999, and in 2002, a new law reduced the number of privileged users only by 20 percent. In Moldova, two program conditions in 1998 referred to the elimination of costly and widespread energy privileges, but they were met with strong political opposition. Only in 2000 were energy privileges streamlined as a prior action for the PRGF program. This paved the way for further tariff increases under the World Bank program supplemented by direct budget subsidies to the poor. In Ukraine, attempts to remove untargeted subsidies on energy and other utilities, as well as abolishing tax exemptions to energy companies failed in 1998. In 2003, Tajikistan's program aimed at eliminating energy privileges and this was achieved as a prior action.

\section{Payment arrears remained widespread}

Only few programs had explicit conditionality on domestic energy arrears. The Armenian 1999 program included a prior action on the completion of restructuring of the energy sector's arrears to domestic creditors. This measure was only partially implemented. In Ukraine, targets on verification and clearance of arrears of the budgetary organizations to energy companies were introduced in 1998. Full clearance was not achieved, instead, budgetary netting operations with energy companies were allowed, while energy arrears of the local governments were restructured over the next five years. The Kyrgyz PRGF programs included performance criteria on the stock of budgetary arrears to KyrgyzEnergo since early 2000, and these targets were generally observed. Since the approval of the threeyear PRGF arrangement in late 2001, no new arrears of the central government to KyrgyzEnergo piled up under the continuous performance criterion. However, offsetting tax liabilities against energy bills continued.

Conditionality was applied also to the energy-related external debt in some highly indebted countries. The adoption of a strategy for netting out energy debts was a prior action for concluding the second review under the Georgian PRGF in 2002, but implementation of this strategy was put on hold as new donor discussions focused on an overall energy sector reform. Tajikistan's program had a prior action on advising foreign energy suppliers of no government guarantees on energy-related debt. In Moldova, the external debt owed to the Russian Gazprom was in part rescheduled and in part swapped for Gazprom's majority equity in Moldovagas.

\section{Mixed results in privatization and regulation}

Privatization of energy companies under Fund conditionality was partially successful in Georgia, Moldova, and Ukraine. In Georgia, the 1997 prior action on the issuance of a privatization plan for Telasi distribution company was observed. Also, a structural benchmark on a private management contract for transmission of electricity was introduced in the second review under the PRGF in July 2002. This benchmark was observed with some delay in early 2003. The program of Moldova stipulated various measures for privatizing Moldovagas, five electricity distribution companies, and power generation in 1999 and 2000. After some delay, three distribution companies were sold to the Spanish firm Union Fenosa 
in early 2000. However, attempts to sell other distribution and generation companies were not successful. Conditionality on privatization was then dropped from the program as it became part of the World Bank's Structural Adjustment Lending (SAL) operation. In Ukraine, the structural benchmark in 1999 to establish the legal framework and complete the preparatory process for privatization of several large enterprises, including power companies, was observed. Since then, there was no further conditionality on energy privatization as these reforms were covered by the Bank program. Fund conditionality in 1999-2001 focused on improving the transparency of Naftogas Ukraine including by setting up a new auditing mechanism. The target to publish the audited data, however, was not observed. In 2000, the Kyrgyz program had conditionality on moving ahead with the privatization of three energy companies (KyrgyzGasMunaizat, KyrgyzGas, and Munai). These steps included completing audits, launching privatization tenders and sale offers, which were not implemented. Subsequently, an external debt strategy was adopted in July 2001 as a prior action for the PRGF. It included the privatization of four power distribution companies with the bulk of privatization proceeds to be used for external debt reduction. By end-2001, the government was required to adopt a specific action plan and time schedule for the privatization of strategic enterprises, including the electricity distribution companies. The plan was approved with a minor delay but no progress was made in privatizing the companies despite the supporting conditionality under the World Bank Country Assistance Strategy (CAS) which covered energy sector reform.

\section{Other measures}

Conditionality in other areas sought solutions for various acute problems. For example, the Ukrainian Extended Fund Facility (EFF) program had targets on conducting gas auctions, as well as measures to liberalize the market for gas sales and imports. Armenia had a structural benchmark on liberalizing the oil product and electricity market in 1995 but the benchmark was not observed satisfactorily. A reporting requirement on cash flows of energy and water sectors for 1999-2000 was implemented. Tajikistan issued a prohibition on new barter trade contracts (except for aluminum) in 1996 as a prior action for its Stand-By Arrangement but on the ground, barter continued.

\section{OUTCOMES AND LESSONS LEARNED}

In 2001, despite the reform efforts in the energy sector and conditionality applied to Fund lending, energy inefficiencies in the sample CIS countries were still high after ten years into reforms (Table 9). While the efficiency of overall energy use had improved in all countries between 1992 and 2001, the progress achieved in the electricity sector was less significant. Although Armenia and Georgia achieved large gains, some countries even backtracked or made virtually no progress (Azerbaijan and Tajikistan). A potential explanation for smaller gains in electricity efficiency compared with the gains achieved in overall energy efficiency is that electricity is a less tradable good than other forms of energy, notably oil products. The law of one price does not seem to apply to electricity as reflected in different actual tariff levels in the sample countries. Thus, market forces have less effect in generating efficiency gains in electricity use and more is left to government discretion in setting prices and enforcing payment compliance. The compliance rate of Fund conditionality on energy sector reforms as discussed above - at 61 percent — is lower than the average compliance rate on 
Fund structural conditionality, suggesting that energy sector reforms are more difficult to implement than structural reforms in other areas.

Table 9. Energy Inefficiency for Selected CIS Countries

\begin{tabular}{|c|c|c|c|c|}
\hline & \multicolumn{2}{|c|}{1992} & \multicolumn{2}{|c|}{2001} \\
\hline & $\begin{array}{c}\text { Energy Use } \\
\text { per PPP } \\
\text { GDP 1/ }\end{array}$ & $\begin{array}{c}\text { Electricity } \\
\text { consumption } \\
\text { per PPP GDP } \\
2 /\end{array}$ & $\begin{array}{c}\text { Energy Use } \\
\text { per PPP } \\
\text { GDP 1/ }\end{array}$ & $\begin{array}{c}\text { Electricity } \\
\text { consumption } \\
\text { per PPP GDP } \\
2 /\end{array}$ \\
\hline Armenia & 0.71 & 1.03 & 0.27 & 0.41 \\
\hline Azerbaijan & 0.76 & 0.55 & 0.50 & 0.64 \\
\hline Georgia & 0.85 & 0.95 & 0.22 & 0.34 \\
\hline Kyrgyz Republic & 0.69 & 1.11 & 0.28 & 0.82 \\
\hline Moldova & 0.82 & 0.98 & 0.53 & 0.57 \\
\hline Tajikistan & 1.30 & 2.36 & 0.53 & 2.34 \\
\hline Ukraine & 0.68 & 0.58 & 0.63 & 0.49 \\
\hline Uzbekistan & 1.57 & 1.40 & 1.26 & 1.01 \\
\hline Simple Average & 0.92 & 1.12 & 0.53 & 0.83 \\
\hline \multicolumn{5}{|l|}{ Memorandum Item: 3/ } \\
\hline Europe \& Central Asia & 0.59 & 0.58 & 0.41 & 0.42 \\
\hline Low Income & 0.35 & 0.18 & 0.25 & 0.15 \\
\hline Middle Income & 0.38 & 0.34 & 0.24 & 0.26 \\
\hline OECD & 0.20 & 0.37 & 0.19 & ... \\
\hline
\end{tabular}

Source: World Economic Outlook (IMF, 2005) and World Development Indicators (World Bank, 2004); and authors' estimates.

1 /Total energy consumption measured in $\mathrm{kg}$ oil equivalent as a ratio to GDP in 2000 purchasing power power parity of the U.S. dollar.

2/Electricity consumption measured in kilo watt hours as a ratio to GDP in 2000 purchasing power power parity of the U.S. dollar.

3/ Country groups as defined in World Development Indicators.

Achieving a breakthrough in eliminating quasi-fiscal deficits is difficult because vested interests in the energy sector would lose from the reform. Indeed, a strong influence of vested interests - as manifested by a weak government, poor regulatory quality, and corruption - is often combined with low efficiency in the country's energy sector (Figure 12). If the government does not have political will and determination to embark on deep reforms in the energy sector, no reform policy works. The ownership of reforms remains suppressed to the power of vested interests and the program conditionality is not effective. In the end - and that might take a long time with significant foregone productivity gains - a country faces a decay of its energy sector capital stock and continuous supply disruptions before the incentive to pay for energy at a full cost-recovery price becomes strong enough to break the stalemate. In Armenia, for example, in the mid-1990s, tariffs were low, cash collection rates were only 30-35 percent and power supply could not be provided for more than two hours a day in many regions. This revealed a true trade-off for energy users between payment and nonpayment leading to significantly improved cost recovery ratios and payments compliance later on. 
Figure 12. Sample CIS Countries: Energy Inefficiency and

\section{Governance 1/}

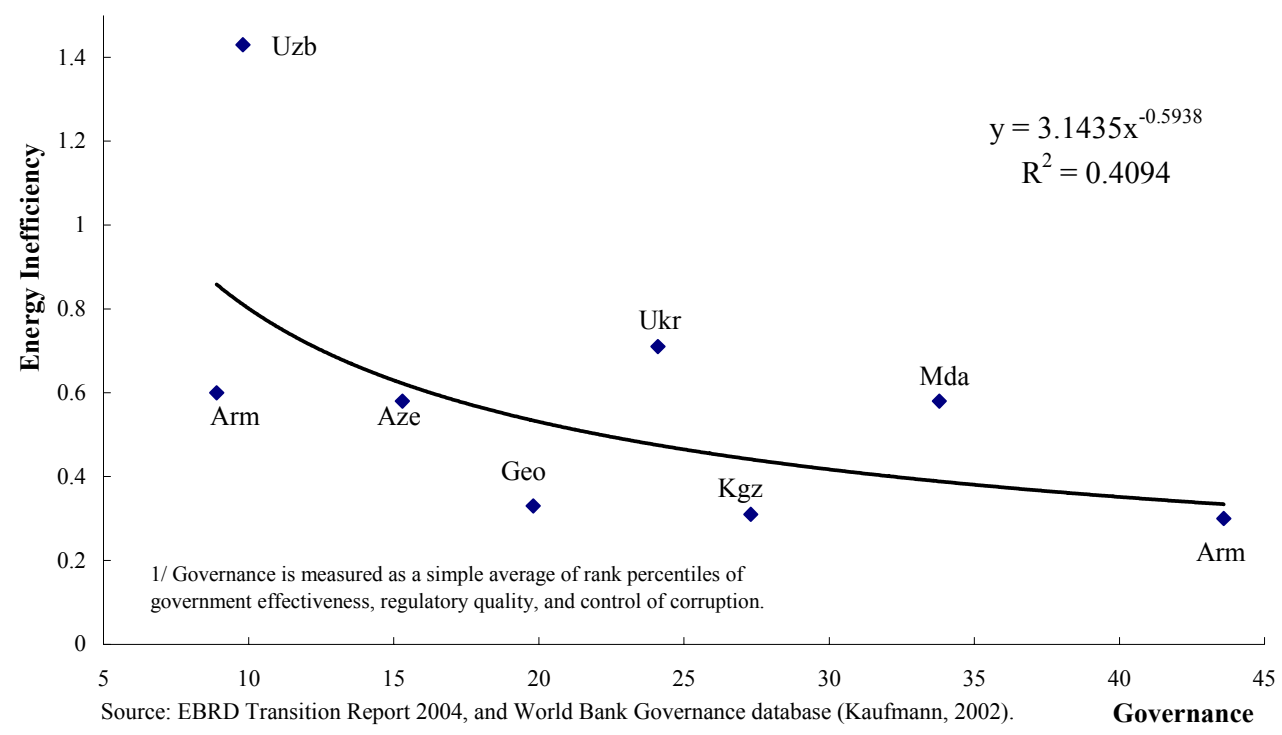

In the CIS, reform inertia is often generated by former state-owned enterprises, which would not be viable with cost recovery pricing of energy. Management of these enterprises has been able to maintain or re-establish strong links to the government and successfully influence the government's (and parliament's) decision making. This state capture is often supported by energy sector officials who are well connected to enterprises and find it more profitable to share the rent extracted from these companies than work on restructuring and privatizing them for outside strategic investors. Anecdotal evidence suggests that in many countries, the job of an electricity meter inspector has become as lucrative as that of tax inspectors. A large part of bills that are collected are not recorded in the company's accounts but shared among insiders. In such an environment, energy sector reform is stalled and energy enterprises are not attractive assets for privatization.

The slow progress in reducing QFDs also reflects governments' sensitivity to social costs of containing the deficit. Many officials and parliamentarians argue that cost-recovery tariffs would be too high relative to the income level of the population. The affordability ratios for electricity estimated by EBRD suggest, however, that on average, the electricity bill was only 3.4 percent of household income in the CIS region in 2000 (Table 10). ${ }^{17}$ To cover the Long Run Marginal Cost (LRMC) of production, payments would need to increase to 6.6 percent of household income. ${ }^{18}$ Of the countries in the sample, spending on electricity was particularly low in Tajikistan, the Kyrgyz Republic, Ukraine, and Azerbaijan. The

${ }^{17}$ EBRD Transition Report, 2001.

${ }^{18}$ As the LRMC estimate, the EBRD used 8 U.S. cents per kilowatt hour-the average retail price in the United States. 
affordability argument, however, is politically relevant in the sample countries because affordability ratios in Russia, the Baltics, and Central Europe also remain low even though payments are broadly consistent with LRMC.

Table 10. Selected Transition Economies: Affordability of Cost Recovery

(Electricity expenditure in percent of household income)

\begin{tabular}{lcc}
\hline & \multicolumn{2}{c}{ Electricity Affordability } \\
\cline { 2 - 3 } Countries, 2000 & Actual & At LRMC prices 1/ \\
\hline Armenia & 8.4 & 11.1 \\
Azerbaijan & 3.8 & 9.3 \\
Georgia & 12.4 & 16.7 \\
Kyrgyz Republic & 1.9 & 9.1 \\
Moldova & 5.2 & 7.3 \\
Tajikistan & 0.2 & 6.6 \\
Ukraine & 2.9 & 5.8 \\
Memorandum Items: & & \\
Russia & 1.0 & 0.5 \\
Baltics & 2.3 & 2.6 \\
CIS & 3.4 & 6.6 \\
Central Europe & 3.6 & 3.5 \\
\hline
\end{tabular}

Source: World Bank; and EBRD.

$1 /$ Share of electricity expenditure in income required to cover long-run marginal cost of power generation and distribution; based on EBRD Transition Report 2001.

The country authorities often argue that tariff policy is not an effective tool to reduce QFDs because tariff increases tend to "leak." Higher tariffs lead to lower collection rates, and imposing conditionality on both tariffs and collection (i.e., effective tariffs) just generates higher losses (theft). For this reason, managerial and ownership reforms must precede tariff and collection reforms. To some extent, the 2002 price hikes in the Kyrgyz Republic demonstrated such offset effects. In April 2002 tariffs were increased by 20 percent, but cash collections declined to 32 percent of billing in 2003, down from 58 percent in 2001.

The data on the broader set of transition countries suggest, however, that the Kyrgyz experience should not be generalized. In Figure 13, actual tariff levels are plotted against bill collection rates. The scatter diagram does not lend support to the "offset argument." On the contrary, the apparent positive correlation between tariffs and bill collection supports the view that higher tariffs and better bill collection could go hand-in-hand. 
Figure 13. Selected CEE and CIS Countries: Bill Collection and Tariffs in 2002

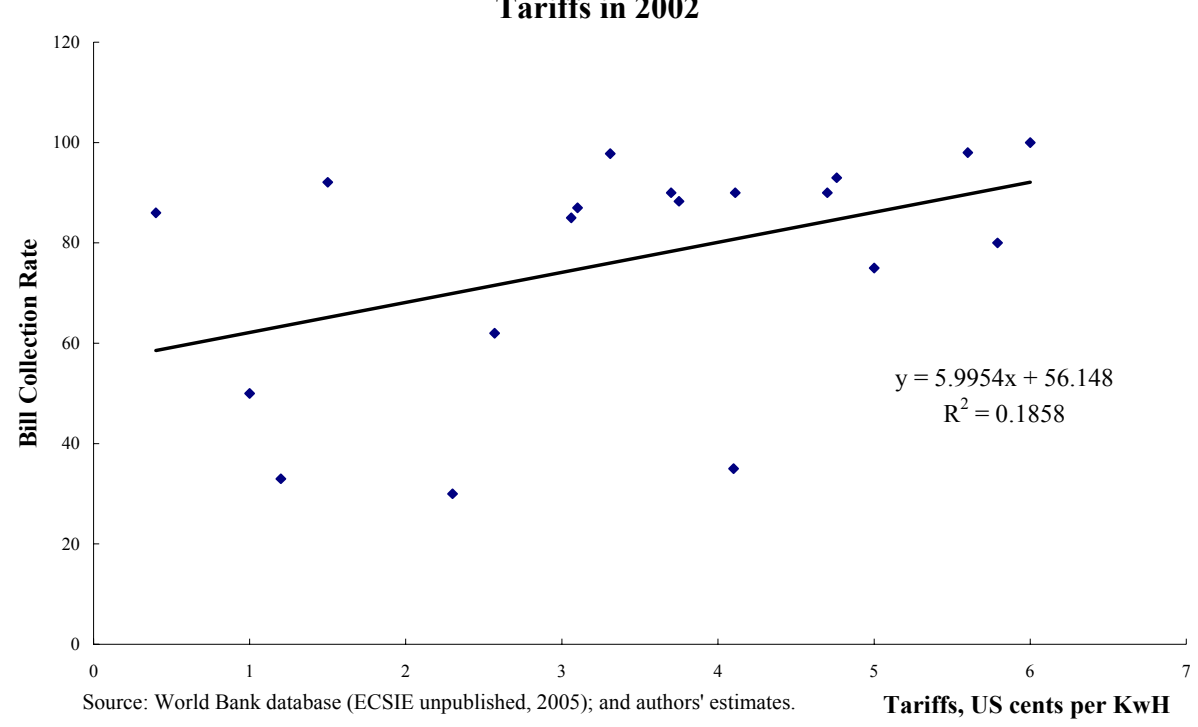

A comparison of tariffs and bill collection rates does not, however, exclude the possibility that the "offset argument" was valid under certain conditions. At low tariff levels, affordability is less problematic and bill collection can be high. However, once tariffs are raised but still remain significantly below cost recovery, the quality of service delivery does not necessarily improve causing frustration among users and the incentive to pay bills declines. Only once tariffs reach the level that is sufficient to finance improvements in the quality of supply, the incentive to comply with higher tariffs will increase. The relationship between tariffs and bill collection could be a U-shaped curve which bottoms out at a threshold level where rising tariffs are believed to improve the quality of supply. To be released from such an offset trap, the overall reform policy must be perceived credible by the public otherwise the payment discipline fails to improve.

Figure 14. Sample CIS Countries: Bill Collection and Tariffs in 2002

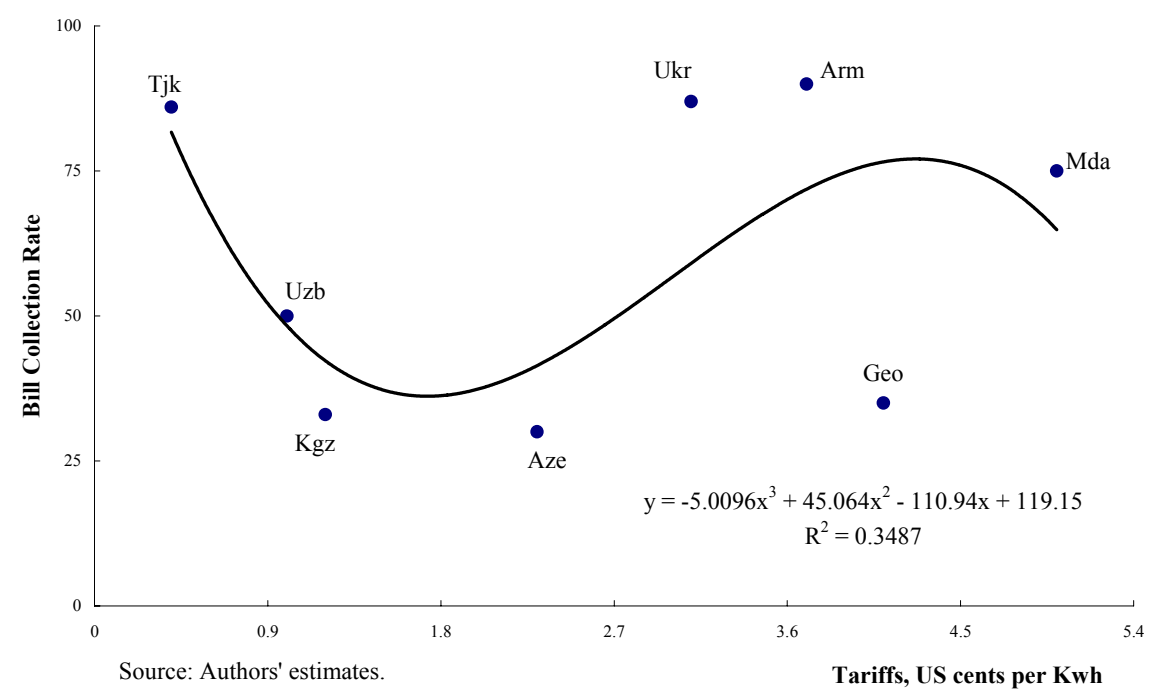


The difficulties in the design of individual policy measures could also explain the limited success of energy sector reforms. Regarding tariffs, setting the target price "right" for cost recovery purposes is a complex task and subject to debate because of lack of reliable cost estimates. An additional complication is that often gains in cost recovery have been reversed by unfavorable macroeconomic developments or external shocks (for example, cost inflation or nominal exchange rate depreciation). On bill collection, the inability to disconnect supplies to noncomplying customers has been a major bottleneck. In part the problem is technical, in part it reflects the governments" long lists of "strategic" customers to which supplies could not be cut off. In Armenia, where tariffs were generally higher than in other countries in the sample, payment enforcement was more effective. A government decree formally supported energy companies to suspend the supply to customers in default, ${ }^{19}$ and an accounting system was established to make the nonpayment transparent. Also, metering systems were improved significantly (including reporting meter manipulations). Successful solutions in other transition countries have included relocation of energy meters in locked boxes and separation of technical meter reading from the commercial function of billing, thereby reducing the scope for collusion between inspectors and consumers. Also, insisting that consumers pay their bills through banks, or well-organized collection centers, instead of providing cash to inspectors, as well as computerizing consumer accounts for better monitoring, have been effective methods in non-CIS transition countries.

The strategy aiming at rapid privatization of utility companies has been only partially successful. In Georgia, blackouts in Tbilisi were reduced after the privatization of the local power distribution company to a U.S. company. The company invested in the metering and billing systems, and provided liquidity to the company. However, it incurred financial problems because of high technical and commercial losses. Its financing from headquarters was cut off and the company stopped paying bills to the Georgian Wholesale Electricity Market. In Moldova, three of the five distribution companies were sold to a Spanish investor in early 2000 and supply cuts were enforced to nonpayers. As a result, in central and southern Moldova, electricity supply became almost uninterrupted. The other two distribution companies remained state-owned because of the lack of investor interest. More recently, however, the government has back-tracked and taken steps to renationalize the privatized power distribution companies. In Ukraine, while several regional power distribution companies were privatized, only a few were sold with full transparency. In Armenia, the sale of four distribution companies failed in 2001 because of lack of investor interest, and the strategy was changed to restructuring these companies and offering a management contract to operate them. One distribution company was privatized in August 2002. In the Kyrgyz Republic and Tajikistan, power privatizations have not attracted strategic investors largely because of low tariffs and the lack of cooperation from Uzbekistan and Kazakhstan to solve the regional water and energy distribution and costing problems. These experiences suggest that sector unbundling and privatization can help but only if good corporate governance and payment enforcement mechanisms are put in place. In more advanced transition countries, there is evidence that the payment problem can be solved through good corporate governance

${ }^{19}$ However, with the exception of government agencies and strategic enterprises. 
even if the companies remain state-owned and vertically integrated (Hungary, Bulgaria, and Poland).

Energy debts complicate privatization. Often, such debts were associated with the countries' efforts to restructure the state debt more generally, including through the Paris Club. By end1999, Armenia had restructured 85 percent of the energy companies' domestic debt and the country's external energy debt was reduced in 2002, through a debt-equity swap with Russia. These measures significantly improved the sector's cash flow thus supporting efforts to improve services delivery. A debt-equity swap was done in Georgia in 2002, when a gas trading company associated with the Russian Gazprom took over a highly indebted Georgian chemical plant. Although Ukraine developed a plan for restructuring debts to energy companies, it was yet to be implemented at end-2003.

\section{Policy Options}

The limited progress in most sample countries' energy reforms reflects a more general transition economy problem: reforms have advanced to a stage where vested interests would lose from further progress and the transition risks to become frozen. ${ }^{20}$ In the CIS countries, the energy sector often harbors influential vested interests. As their resistance to deeper reforms has increased, the ownership of energy reform has declined. A breakthrough requires overcoming the influence of vested interests which suggests that a prerequisite for effective reform is good corporate and public administration governance. Effective program conditionality would call for a reduced scope for state capture, it would cover the loopholes for circumventing conditionality, and it would minimize social costs of the reform.

The best option would be to include an audit-based quasi-fiscal deficit of the energy sector as a separate performance criterion in Fund-supported programs. In this case, no further energy conditionality would be required by the Fund. However, so far reliable business accounting is lacking in most CIS countries' energy companies. Progress needs to be made in applying International Accounting Standards (IAS) and developing auditing profession before performance criteria based on an overall financial balance can be effectively used as conditionality. The benefit of such an overall financial balance approach would be that it would cover all operations of the energy sector providing little room for evading conditionality. It would also give flexibility to the government to choose the menu of specific policy measures independently which could improve ownership. In addition, audit-based accounts would improve transparency thus reducing the scope for vested interests to influence the energy sector.

The second best option would be to set the energy sector's quasi-fiscal deficit as a performance criterion by using the end-user approach as a yardstick. This option would be more suitable for countries with less developed accounting systems. Meanwhile, energy enterprises should be audited by internationally reputable auditing firms and adopt IAS-based accounting to move gradually to financial balance approach in defining the quasi-fiscal

\footnotetext{
${ }^{20}$ For studies that review the influence of oligarchs on the reform process in the transition countries, see the World Bank (2002), and Havrylyshyn (forthcoming).
} 
deficit. The deficit of the energy sector should be included in the annual budget documentation to make the cost and financing of quasi-fiscal activities transparent, revealing the fiscal trade-offs to the public.

The third reform option with lower ambition level would be based on a governance approach. In this option, the influence of the vested interest would be reduced by improving governance in the energy sector without addressing the quasi-fiscal balance directly. Under Fund conditionality, the cost of a quasi-fiscal deficit would be made explicit in the government budget to increase transparency and accountability. Fund conditionality could also cover budgetary flows related the energy sector. These would include a zero tolerance of arrears on energy bills, taxation of utility consumption, restructuring of the energy sector's tax arrears and external debts, and providing social transfers for the poor in exchange of canceling discounted tariffs for energy use. Tariff reform, cash collections, losses, and management issues would remain under World Bank conditionality as many such measures fall outside the Fund expertise. Only if a Bank operation is not in place, would Fund conditionality selectively cover such measures.

The final option is to cope with blackouts. If the reform program lacks ownership-i.e. the political will to tackle vested interests and the capture of the energy policy is missing-reforms will only take place through crisis. Severe supply crisis would raise the awareness of the population about the necessity of tariff increases and payment discipline. This option, however, could take a long time to materialize which would increase the cost of adjustment.

Overall, the reforms need to be successful in strengthening the linkage between higher cost of services and better access to and quality of energy supply. ${ }^{21}$ The dilemma is that it is difficult to improve access and quality without increasing effective tariffs, but it is also difficult to raise tariffs without improving access and quality. All policy options require vulnerable segments of the population to be appropriately compensated for higher energy costs. General wage increases are likely to be sufficient to protect the average wage earner. As long as overall inflation is contained and real wages rise, higher tariffs effect only relative prices and thus should not meet overwhelmingly strong resistance. At the same time, an explicit link between energy costs and social safety net in the budget would make the policy more transparent as both measures would be discussed and approved simultaneously by parliament. Finally, because economic (and therefore fiscal) gains from the energy sector reform are significant in the longer term, the social compensation for short-term losers should not be seen as a risk for fiscal stability.

${ }^{21}$ Energy reform under auspices of the World Bank could be complementary in eliminating the quasifiscal deficit in the medium term, and could well make use of the Bank's expertise in measures on tariffs, collection, losses, theft, and management issues, as well as its technical assistance for implementation. 


\section{EPILOGUE}

The estimates of QFDs presented in this paper date back to 2002 and the period for the conditionality analysis ended in 2003. More recently, many countries in the sample have made progress in addressing the energy sector financial imbalances. Nevertheless, the issues remain largely as discussed above and only Armenia seems to be near the completion of the long road to financial stability in the energy sector.

In Armenia, separate companies have been created for financial settlements, electricity dispatch, and high voltage distribution and independent boards of directors have been appointed for the new companies. While tariffs covered costs already in 2002, bill collection rates are reported to have risen to 100 percent and losses have declined further. As a result, the quasi-fiscal deficit in the electricity sector has been virtually eliminated. A remaining issues is how to deal with the debts the sector accumulated in the past.

In Azerbaijan, the cost recovery ratio of natural gas has reportedly risen to 85 percent by end2004 from 50 percent in 2002 but bill collection rates remain at around 50 percent. Regarding electricity, the national oil monopoly (SOCAR) continues to provide underpriced fuel and gas inputs to power generation. Tariffs are below cost recovery levels and the collection of payments remains ineffective.

Georgia has made progress in improving bill collection through more forceful supply disconnection policy and further expansion of customer metering. As a result, the bill collection rate rose from 35 percent in 2002 to over 50 percent in 2004. During this period, however, tariff increases lagged cost increases and the cost recovery ratio declined to 94 percent. In 2004, the PRGF-supported program introduced indicative targets for bill collections of electricity and gas.

The QFD of the Kyrgyz electricity sector has declined from 12 percent of GDP in 2002 to below 9 percent in 2004 but this estimate does not take into account the potential increase in the cost recovery level in the last few years when, for example, the world market price of oil has increased significantly. The new PRGF-supported program approved in early 2005 continues to include the QFD as an indicative program target.

In Moldova, the energy related debt to foreign suppliers remains sizeable and dependency on natural gas imports - the main source of energy - leaves the country vulnerable to potential fluctuation in the import price. Also, collection and pricing losses have not abated as reforms in the sector are still left incomplete.

While Tajikistan's gas tariffs are at the cost recovery level, power tariffs do not cover costs despite the tariff hikes in 2003. The World Bank estimates suggest that to achieve cost recovery, tariffs would have had to increase fourfold in 2004. With some further tariff rationalization, cost recovery has improved since and the authorities estimate that the combined electricity and gas QFD may have declined to nearly half of the level observed in 2002. The 2005 PRGF-supported program introduced a structural benchmark for auditing the TajikGas monopoly. 
Ukraine has made progress in improving the collections of electricity bills reportedly achieving a 90 percent collection rate at end-2004. An overall better cost recovery is also being achieved given the increased significance of industrial consumption-where tariffs are highest. A key test is to improve the cost recovery ratio in gas supplies. ${ }^{22}$

The Uzbek authorities have reportedly increased electricity tariffs significantly in 2003-04 thus raising the cost recovery ratio from 28 percent in 2002 to about 70 percent in 2004. At the same time, collection rates have improved.

${ }^{22}$ Based on economic costs including the gas import price (approximately $\$ 54 / \mathrm{tcm}$ ), local transport and gas conversion fees, and depreciation cost (estimated at about $\$ 10 / \mathrm{tcm}$-Table 5) but excluding long-term expansion, the current average gas tariff covers around 80 percent. 


\section{References}

EBRD, Transition Report (various year issues)

Dodsworth, John R., Mathieu, Paul H., and Shiells, Clinton R., 2002, "Cross-Border Issues in Energy Trade in the CIS Countries," IMF Policy Discussion Paper, PDP/02/13 (Washington: International Monetary Fund).

Havrylyshyn, Oleh, (forthcoming) “Capitalism for All, or Capitalism For a Few?"

Hellman, Joel S., Geraint Jones, and Daniel Kaufmann, 2000, "Seize the State, Seize the Day - State Capture, Corruption, and Influence in Transition," World Bank Policy Research Working Paper No. 2444, (Washington: World Bank)

Kaufmann, Daniel, Aart Kraay, and Massimo Mastruzzi, 2003, "Governance Matters III: Governance Indicators for 1996-2002,” (unpublished June 2003 draft; Washington: World Bank)

Mathieu, Paul H., and Clinton R. Shiells, 2002, “The Commonwealth of Independent States' Troubled Energy Sectors," Finance and Development, (September), pp. 34-38.

Petri, Martin, Günther Taube, and Aleh Tsyvinski, 2002, "Energy Sector Quasi-Fiscal Activities in the Countries of the Former Soviet Union," IMF Working Paper, WP/02/60 (Washington: International Monetary Fund).

World Development Indicators 2004, World Bank, March 2004.

World Bank, 2002, "Transition-The First Ten Years: Analysis and Lessons for Eastern Europe and the Former Soviet Union" (Washington) 

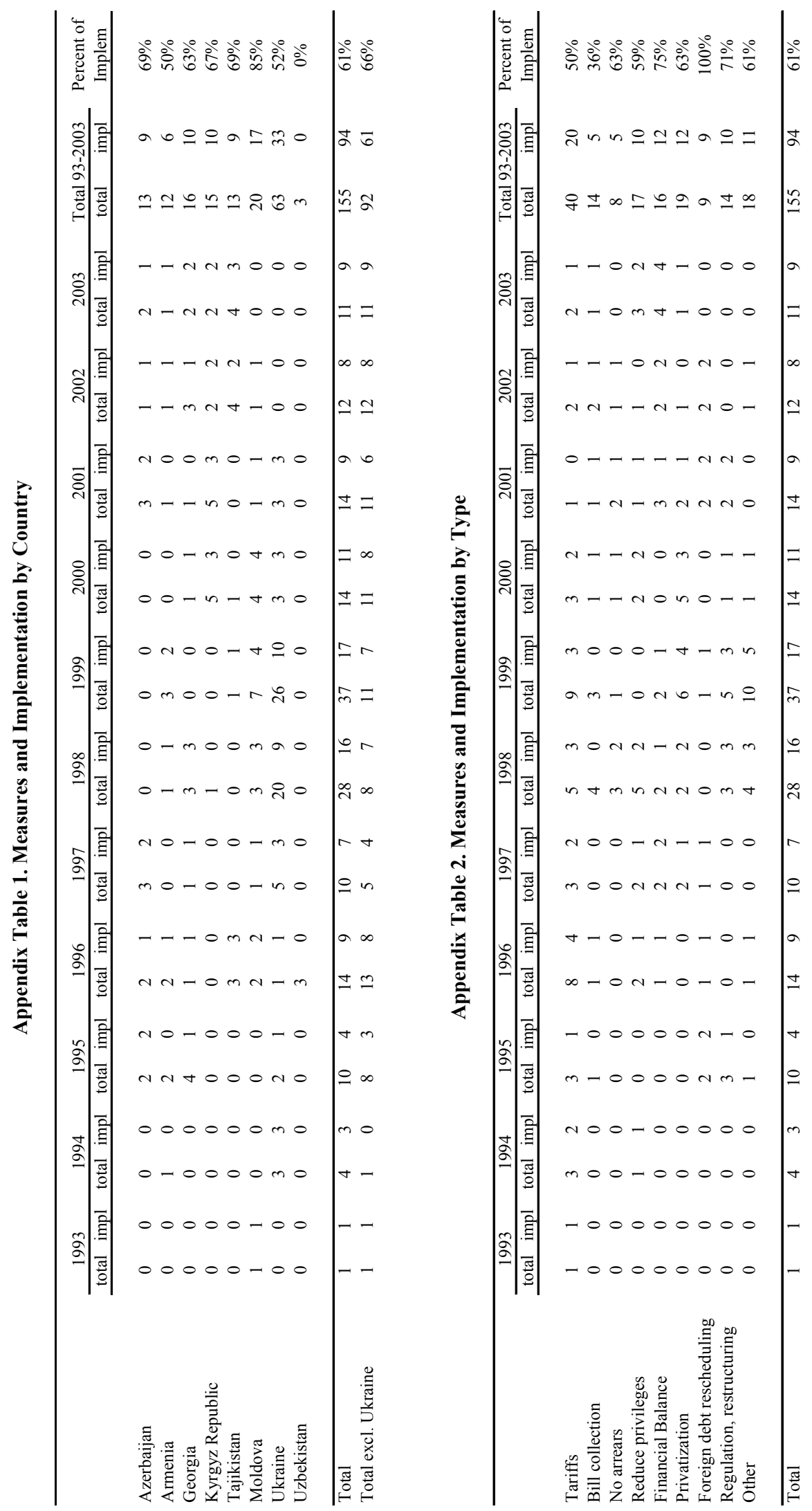


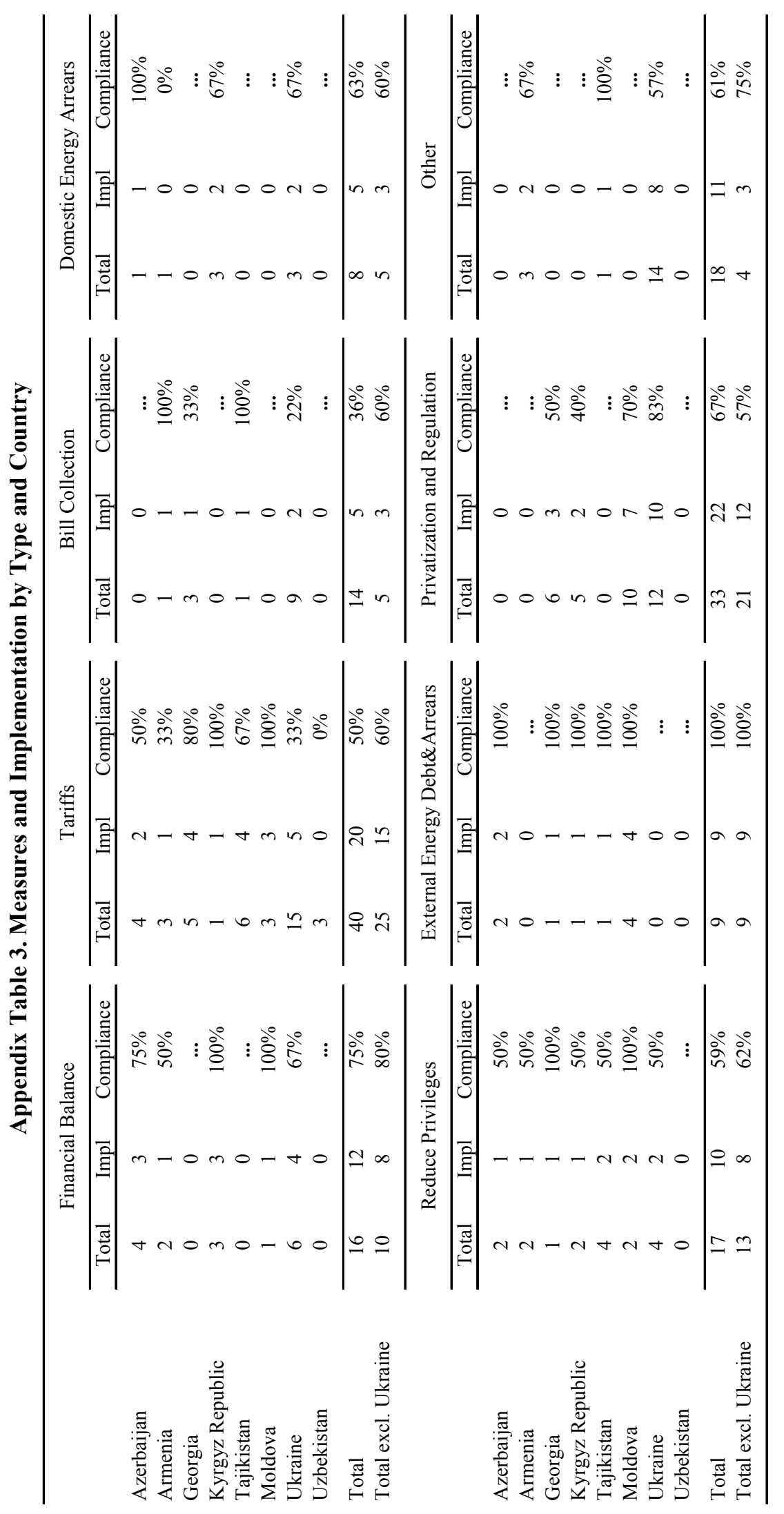




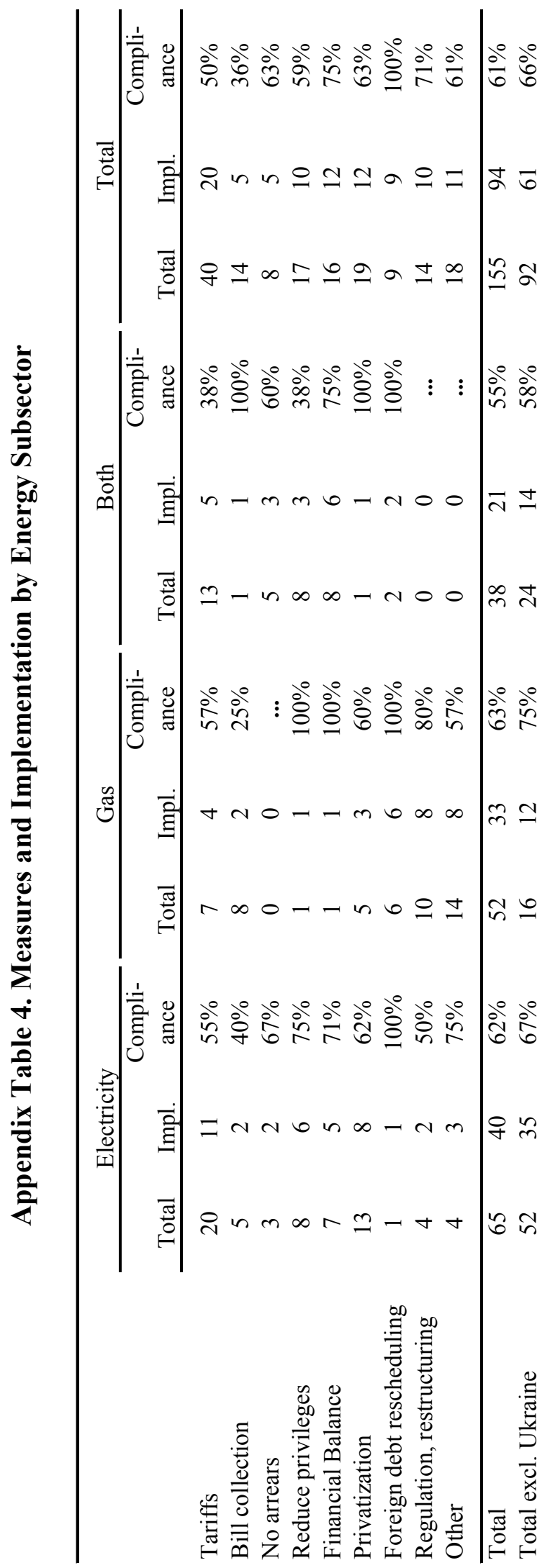




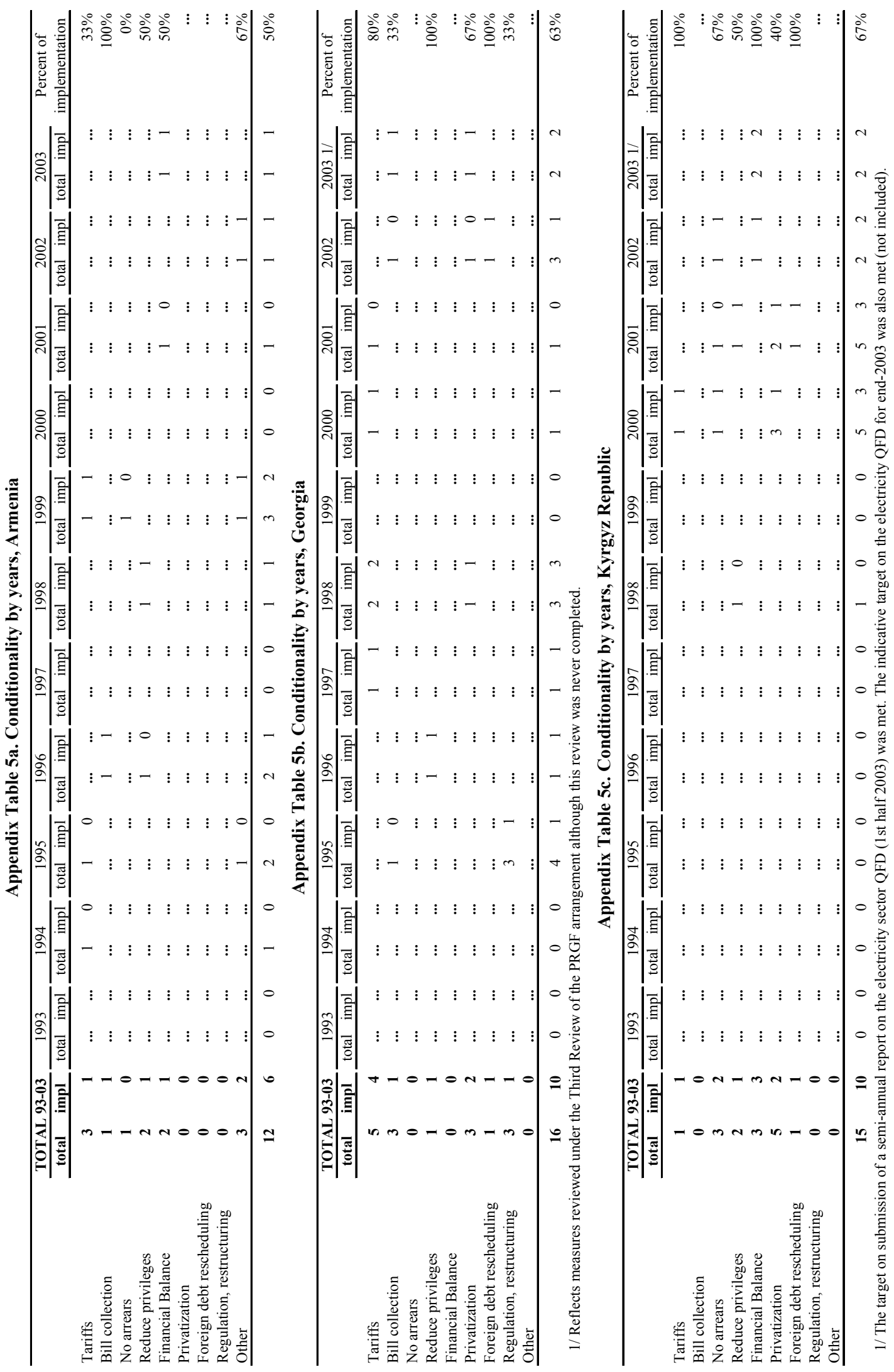




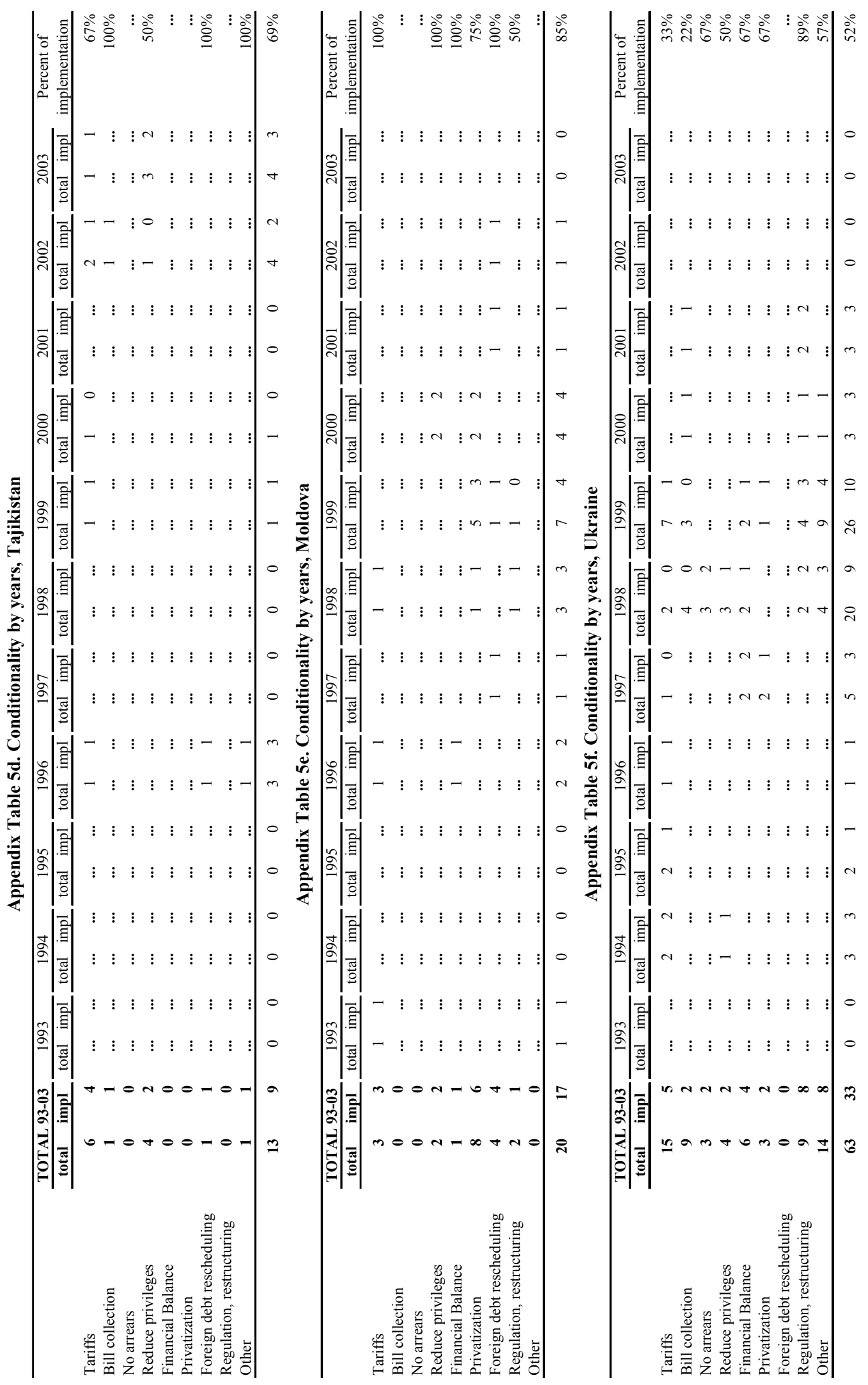




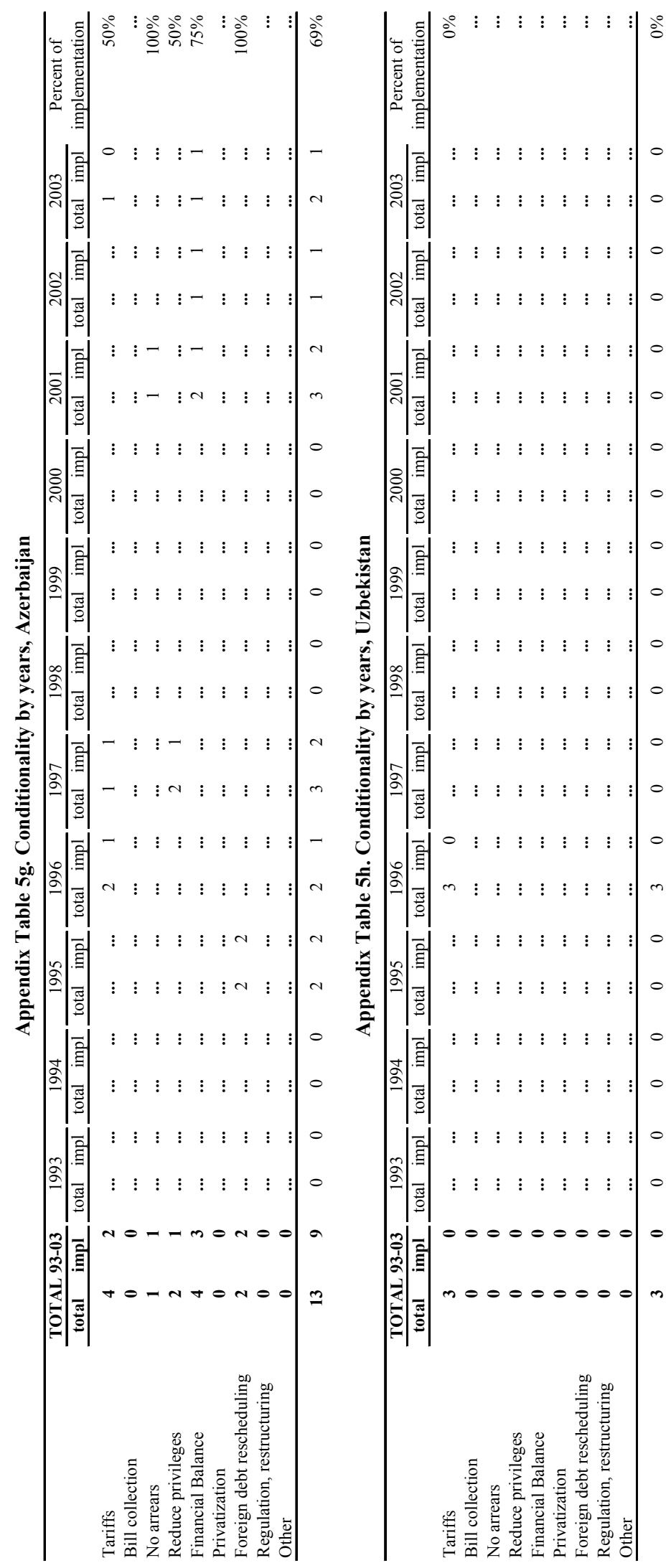

